This item was submitted to Loughborough's Research Repository by the author.

Items in Figshare are protected by copyright, with all rights reserved, unless otherwise indicated.

\title{
Terminal sterilization: Conventional methods versus emerging cold atmospheric pressure plasma technology for non-viable biological tissues
}

\section{PLEASE CITE THE PUBLISHED VERSION}

http://dx.doi.org/10.1002/ppap.201600134

\section{PUBLISHER}

(c) Wiley-VCH Verlag

\section{VERSION}

AM (Accepted Manuscript)

\section{PUBLISHER STATEMENT}

This work is made available according to the conditions of the Creative Commons Attribution-NonCommercialNoDerivatives 4.0 International (CC BY-NC-ND 4.0) licence. Full details of this licence are available at: https://creativecommons.org/licenses/by-nc-nd/4.0/

\section{LICENCE}

CC BY-NC-ND 4.0

\section{REPOSITORY RECORD}

Marsit, Nagi M., Laura E. Sidney, Matthew J. Branch, Samantha L. Wilson, and Andrew Hopkinson. 2019. "Terminal Sterilization: Conventional Methods Versus Emerging Cold Atmospheric Pressure Plasma Technology for Non-viable Biological Tissues". figshare. https://hdl.handle.net/2134/23656. 
1 Terminal sterilization: Conventional methods versus emerging cold atmospheric

2 pressure plasma technology for non-viable biological tissues

3

4 Authors

5 Nagi M. Marsit: Academic Ophthalmology, Division of Clinical Neuroscience, Queen's

6 Medical Centre Campus, University of Nottingham, Nottingham, United Kingdom

7 Department of Human Tissue, Biotechnology Research Center (BTRC), Libyan Authority for

8 Research, Sciences and Technology, Tripoli, Libya

11 Laura E. Sidney: Academic Ophthalmology, Division of Clinical Neuroscience, Queen's

12 Medical Centre Campus, University of Nottingham, Nottingham, United Kingdom

Matthew J. Branch: Academic Ophthalmology, Division of Clinical Neuroscience, Queen's

Medical Centre Campus, University of Nottingham, Nottingham, United Kingdom

Samantha L. Wilson: Academic Ophthalmology, Division of Clinical Neuroscience, 20 Queen's Medical Centre Campus, University of Nottingham, Nottingham, United Kingdom

23 Andrew Hopkinson: Academic Ophthalmology, Division of Clinical Neuroscience, Queen's 24 Medical Centre Campus, University of Nottingham, Nottingham, United Kingdom

26 Corresponding author

27• E-mail address:andrew.hopkinson@nottingham.ac.uk

28 Academic Ophthalmology, Division of Clinical Neuroscience, Queen's Medical Centre

29 Campus, University of Nottingham, Nottingham, United Kingdom

30. Correspondence

31 Andrew Hopkinson, Academic Ophthalmology, Division of Clinical Neuroscience, Queen's

32 Medical Centre Campus, University of Nottingham, Nottingham, NG7 2UH, United

33 Kingdom.

34 Email:andrew.hopkinson@nottingham.ac.u 


\section{Abstract}

37 Tissue products are susceptible to microbial contamination from different sources, which may

38 cause disease transmission upon transplantation. Terminal sterilization using gamma

39 radiation, electron-beam, and ethylene oxide protocols are well-established and accepted,

40 however, such methods have known disadvantages associated with compromised tissue

41 integrity, functionality, safety, complex logistics, availability, and cost. Non-thermal (cold)

42 atmospheric pressure plasma (CAP) is an emerging technology that has several biomedical

43 applications including sterilization of tissues, and the potential to surpass current terminal

44 sterilization techniques. This review discusses the limitations of conventional terminal

45 sterilization technologies for biological materials, and highlights the benefits of utilizing CAP.

46

47 


\section{INTRODUCTION}

49 Tissues and biological transplant materials (TBTM), including bone, soft tissues, and other

50 biologically derived biomaterials should be sterilized to prevent transmission of

51 microorganisms to the recipient. TBTM typically possess a natural microbial

52 load/bioburden $\underline{1}$ or acquire one during collection and processing. If not eliminated, this has

53 the potential to cause an infection leading to transplant failure, and further harm to the patient.

54 Prevention of disease transmission is of primary concern to TBTM manufacturers and the 55 regulatory authorities.

56 Sterilization is the confident and reproducible elimination of all forms of life. Terminal

57 sterilization is considered the final step in the manufacturing process of a sterile product in its

58 final packaging.[1] Terminal sterilization is used in the processing of TBTM to provide

59 sterility assurance and is generally mandated by national regulatory authorities.[2] Terminal

60 sterilization is required when: TBTM are processed in non-aseptic conditions; are not treated

61 by any other form of decontamination; use non-sterile consumables; or are stored in

62 conditions that do not prevent microbial growth. There is no ideal sterilization process for all biological materials. Each strategy faces advantages and disadvantages, requiring numerous considerations when choosing sterilization methods, including:

- Material compatibility.

- Reliability against bacterial spores, endotoxins, and viruses.

- Effect on production process.

- Expense.

69 Although terminal sterilization destroys contaminating microbial agents, the process also 70 devitalizes the cells of the tissue. As a result, terminal sterilization is unsuitable for TBTM 71 that are intended to include viable and healthy donor cells. Non-viable TBTM are routinely used for diverse applications ranging from homotopic, long-term transplants such as bone grafts $[\underline{3,4}]$; to short-term heterotopic transplants, such as amniotic membrane (AM) which can be used as an ocular surface bandage. $[\underline{\mathbf{5 , 6}}]$ In these situations, terminal sterilization is appropriate. Preservation of the original structure and function of a tissue, both mechanically and biochemically is essential. However, most sterilization methods can substantially damage biological materials. 
Classical terminal sterilization methods such as ionizing radiation and ethylene oxide (EtO) have limitations including TBTM degradation, prolonged sterilization cycles, cost, logistical difficulties and inefficiency against viruses, prions, and endotoxins. Thus, an effective sterilization procedure capable of maintaining a balance between sterilization efficacy, cost, and retention of TBTM structural and functional properties is required for elimination of such resistant contaminants.

Trials of non-thermal (cold) atmospheric pressure plasma (CAP) sterilization methods on viable cells and tissues are promising.[1]-11] Although CAP is potentially restricted to the sterilization of thinner TBTM, further optimization could deliver reduced cost, time, logistics, and damage. In contrast with conventional sterilization methods, literature has reported that CAP possesses the ability to eradicate all resistant contaminants such as viruses, prions, endotoxins, and biofilm from the treated surfaces. $[\underline{12,13}]$

This review compares the limitations of classic terminal sterilization of TBTM including gamma $(\gamma)$, electron beam (e-beam) and EtO, and addresses the possibility of implementing CAP technologies with a particular focus on the sterilization of non-viable AM.

\section{CHALLENGES OF TBTM MANUFACTURING AND RISK OF} CONTAMINATION

Tissue processing protocols vary, depending upon tissue structure and composition and the intended application, which determines how well the structural and functional properties of the native tissue need to be maintained. Processing of TBTM may include dissection, intensive, and prolonged washing steps to remove blood and cellular components to diminish the presence of antigens and disease, defatting, demineralization, and decellularization.

TBTM may be preserved dry, or in hydrated form, at ambient or cold storage conditions; they may be aseptically prepared, high level decontaminated, or terminally sterilized.[14] Optimized manufacturing procedures are crucial for the quality and safety of the final product. There are specified international regulatory directives set to ensure prevention of risk from communicable disease transmission agents during procurement, processing, preservation, storage, and use of TBTM (Directive 2004/23/EC).[1] In the UK, under Human Tissue Authority (HTA) regulations, viable and non-viable tissues can be prepared without terminal sterilization. However, such procedures require stringent preparation and in-process monitoring compared with terminally sterilized tissues. Long-term 
110 storage of cryopreserved tissue requires specialist storage at $-135^{\circ} \mathrm{C}$ and with specific

111 cryoprotectants such as dimethyl sulfoxide or glycerol; whereas non-viable, dehydrated

112 (freeze-, heat-, or vacuum-dried) tissue can be vacuum-packed and stored at ambient

113 temperature for up to five years.[투

114 In the US, transplantable materials such as bone, tendon, ligament, dura mater, heart valves,

115 skin, cornea, and AM are designated as "human cell, tissue, cellular or tissue-based products"

116 (HCT/P) by the US Food and Drug Administration (FDA), with the stipulation that it is

117 minimally manipulated as regulated under section 361 of the Public Health Service Act

118 (PHSA) and the Code of Federal Regulations (CFR no. 21, Parts 1270 and 1271 of the FDA

119 cGTP). Minimal manipulation is defined as negligible alteration to the tissues' original

120 biological structure including physical integrity, tensile strength, and elasticity; while

121 allowing for preservation via drying, cryopreservation, and denuding (removal of

122 epithelium).[17] FDA regulation does not mandate terminal sterilization for HCT/Ps,

123 however, aseptic processing must be used during tissue manufacturing to prevent

124 contamination.[18 $]$

125

126

\subsection{Amniotic membrane as an example of a TBTM}

127 AM is a TBTM that has a long history of surgical use, but has varied processing techniques

128 and associated challenges. AM can be used for membrane repair on wound surfaces, or to fill

129 spaces left by non-healing ulcers.[19-21] AM is commonly used in ophthalmic applications

130 to treat a variety of corneal conditions.[5] Alongside acting as a transparent, physical shield,

131 AM reportedly possesses protective, antimicrobial, analgesic, and anti-inflammatory

132 properties, that promote wound healing. $[\underline{\mathbf{5}, \mathbf{6}}]$ Due to its healing properties and low

133 immunogenicity, AM is often applied directly to open wounds.

134 AM undergoes stringent and tightly regulated processing procedures for clinical application.

135 AM is typically collected from women undergoing preplanned, full-term elective cesarean-

136 sections.[22] Therefore, donor screening, which involves assessment of information on health

137 and social history, is the first line in disease transmission prevention. Donors must comply

138 with set inclusion criteria, for example test-negative for human immune-deficiency virus

139 (HIV), hepatitis B virus (HBV), hepatitis C virus (HCV), and Treponema pallidum (syphilis),

140 among other criteria.[23, 24]

141 Under normal health, AM is naturally free of bioburden while in the womb. However, normal

142 flora of the lower genital tract (e.g., gram-positive and gram-negative aerobic and anaerobic 
143 organisms such as genital mycoplasmas and Streptococcus agalactiae), are capable of

144 crossing intact membranes to invade the amniotic cavity during labor.[25] However, AM

145 obtained from healthy full-term cesarean sections should have no bioburden. The UK

146 advisory committee on Safety of Blood, Tissues and Organs (SaBTO) guidelines state that:

147 "Estimation of bioburden of skin and amnion is not recommended as the former carries a

148 substantial bioburden and the latter is surgically recovered under aseptic conditions. However,

149 a heavy growth of bacteria from pre-process samples may signify gross contamination and

150 the tissue should not be released unless able to be terminally sterilized by irradiation or other

151 techniques. The potential damage to the integrity of the tissue by the high numbers of bacteria

152 should also be considered before it is used for transplantation.”[26 ]

153 Cesarean deliveries do have the potential to introduce some contamination, likely originating

154 from the donor's skin microbial flora, transmitted during AM removal.[27, 28] Other

155 contamination may arise from the operating room environment. Further processing of AM

156 usually takes place in GMP environments subjected to high-level decontamination procedures.

157 AM is generally rendered non-viable during preservation, either by drying or freezing.[29] As

158 a non-viable tissue, currently used surgically, AM is an ideal candidate for terminal

159 sterilization.

160

\section{STERILIZATION OF ABNORMAL BIOLOGICAL CONTAMINANTS}

162 Processing and sterilization protocols are effective for TBTM with low to normal bioburden.

163 Tissues infected with a high bioburden of endotoxin producing, gram-negative bacteria or

164 virulent, antibiotic-resistant bacteria, for example pseudomonas, methicillin-resistant $S$.

165 aureus (MRSA), or C. difficile, represent a greater hazard and are unsuitable for

166 transplantation unless a terminal sterilization procedure is used, that is validated for effective

167 removal or complete inactivation of microbial loads.[30] TBTM can also be contaminated by

168 non-living biological agents such as endotoxins, prions, and viruses, which are known to

169 resist most conventional sterilization methods.[31] Most ISO standards exclude viruses and

170 prions from their sterilization validation documents. For example, ISO 14160:2011[프] for

171 liquid chemical sterilization controls risks associated with only bacteria and fungi

172 contamination; however, it is not applicable to TBTM. Also, ISO 11137-1:2006,[33] for

173 validation of radiation sterilization dose does not cover viral contamination and ISO

174 11135:2014,[34] for validation and control of EtO sterilization methods excludes prion 
175 contamination from its scope. Categorically, these standards indirectly recognize the

176 downsides of industrial sterilization technologies toward particular contaminations.

177 The risk of harvesting and transplanting infected tissue can be reduced, but not eliminated, by

178 specific donor exclusion criteria in the form of detailed medical/social history questionnaires

179 and advanced serological testing. However, terminal sterilization remains the most effective

180 method for eliminating biological contamination hazards associated with donor source,

181 procurement, and manufacturing. Selection of the appropriate sterilization protocol for

182 TBTMs must be considered on a case-by-case basis; considering the possibility of

183 sterilization resistant contaminants.

\section{$184 \quad 3.1$ Endotoxins}

185 Endotoxins are the lipopolysaccharides (LPS) that make up the outer membranes of the 186 pathogenic and non-pathogenic gram-negative bacteria.[35] Endotoxins present in the blood 187 stream are life-threatening in high doses,[36] due to activation of the immune system causing 188 “endotoxin shock.” Current sterilization technologies only deactivate endotoxin producing 189 bacterial species and are incapable of removing endotoxins themselves. Therefore, there is 190 potential endotoxin existence on sterile products. Endotoxin contamination is of great 191 concern in pharmaceutical and TBTM manufacturing industries, as they are thermostable, 192 resistant to $\mathrm{pH}$ change, vary widely in size, and have heterogeneous molecular structures.[37, 193 38] Aggressive endotoxin removal methods such as high temperatures $\left(250^{\circ} \mathrm{C}\right.$ for 30 min, or $194180^{\circ} \mathrm{C}$ for $3 \mathrm{~h}$ )[39] are unsuitable for TBTM. The terminal sterilization radiation doses 195 required to degrade endotoxins are effective only at very high levels,[눙 which can be destructive to TBTM. As product removal of endotoxins is more problematic than sterilization; avoiding contamination by employing aseptic technique and current good tissue practice (cGTP) are currently the favored approach.

\subsection{Prions}

201 Prions are another challenging form of non-living contamination. They are a pathogenic form 202 of misfolded protein responsible for introducing neurodegenerative disorders such as 203 transmissible spongiform encephalopathies. These potentially fatal prion diseases can be transmitted to healthy patients through contaminated tissue allografts such dura mater and ocular tissue transplants.[41] Prions exhibit a resistance to most known physical and chemical sterilization methods. Even methods combining autoclaving with chemical treatment of 
207 concentrated sodium hydroxide are incapable of completely abolishing prion contamination 208 from reusable hospital devices.[42]

211 A biofilm is a complex stratified mass of single or varied genotypes of microbes (bacteria or 212 fungi), compacted to each other and strongly attached to surfaces. Biofilms have high 213 protection capacity against disinfectants and antimicrobials compared to normal microbial 214 form. Thickness and compaction determines microbial biofilm resistance to penetrating 215 oxidative agents. Biofilms are formed on synthetic transplant materials,[43] but are not 216 known to be present on TBTM. However, biofilm presence in water pipes, channels, and 217 surfaces of TBTM manufacturing equipment can be a source of frequent contamination, 218 representing a considerable safety concern. Once these biofilm making microorganisms reach 219 the manufacturing equipment and materials, a reliable sterilization technique is required to 220 eradicate it. Examples of biofilm forming bacteria include: MRSA, Staphylococcus 221 epidermidis (S. epidermidis), Staphylococcus aureus (S. aureus), and Escherichia coli (E. 222 coli).[43]

\subsection{Viruses}

225 Non-viable TBTM that have been exposed to chemical treatment, drying or terminally 226 sterilized are less virally infectious than viable tissue preserved at low temperatures.[44] 227 Therefore, transmission of viruses through non-viable TBTM is rare. However, viruses with 228 small, and/or double stranded genomic material have more ability to repair damage to genetic 229 material than viruses with complex genomes,[4] $]$ and can resist high radiation doses of $230100 \mathrm{kGy} \cdot[\underline{46}]$

\section{ESTABLISHED STERILIZATION TECHNIQUES FOR TBTM}

233 Challenges of TBTM manufacturing include standardization, maintenance of tissue quality, 234 and sterility, which may ultimately affect clinical outcome. The predominant issue with 235 contemporary terminal sterilization techniques such as $\gamma$, e-beam, and EtO, is maintenance of 236 tissue structure and biological properties.[47] However, failure to provide sterile TBTM can 237 result in significant health complications, and cost implications to health care providers. 
239 High temperature sterilization techniques, such as high-pressure steam methods, are

240 unsuitable due to their denaturing and destructive effects on tissue extracellular matrix; they

241 can also coagulate soft tissues[ $\underline{48}]$ and are insufficient for endotoxin inactivation. Other non-

242 thermal, conventional sterilization methods such as EtO, $\gamma$, and e-beam are recognized

243 techniques, which are effective when validated correctly.[42] Radiation dosage for

244 sterilization is validated using ISO 11137 (2006), EtO, and pressured steam sterilization are

245 also standardized by ISO 11135 (2014) and ISO 17665-1 (2006)[누] respectively.

246 The achievement of absolute sterility is difficult to determine without destructively testing all

247 batch materials.[무 ] Therefore, sterile production standards of medical supplies, drugs and

248 TBTMs refer to the sterility assurance level (SAL). SALs are based on the theoretical

249 probability of overkill and demonstration of non-sterility of a particular item following

250 sterilization. SAL $10^{-6}$ is adopted for medical devices and biological products and is endorsed

251 by most major tissue banking societies and specialized organizations.[51, 52] Using SAL

$25210^{-6}$ implies that no more than one item in one million may be non-sterile, or that there is a

253 one in a million chance that an individual microbe will survive sterilization. Nevertheless, the

254 FDA does not specify a particular method of terminal sterilization or a specific SAL for

255 TBTMs. SAL selection is the tissue manufacturer's responsibility and appropriate SALs

256 lower than $10^{-6}$ can be used if the product is unable to withstand the sterilization process

257 (AAMI ST67 standard). SAL $10^{-3}$ is used for inanimate medical supplies and have not been

258 reported to be less assured than SAL $10^{-6}$ products in terms of preventing nosocomial

259 infections $\underline{2}$. Although current terminal sterilization techniques have revolutionized many

260 industries including medicinal products and tissue supply, higher SALs may come at the cost

261 of damaging TBTM.[53]

\subsection{Limitations of current low temperature sterilizations}

264 Current terminal sterilization techniques along with their advantages and disadvantages with 
269 Table 1. Physical and chemical terminal sterilization techniques and their advantages and

270 disadvantages

\section{Technique}

Physical

Pressurized steam (autoclaving)
Inexpensive simple, safe, rapid, and efficient, leaves no toxic residues.[프]

\section{Advantages}

\section{Disadvantages}

Incompatible with tissues and polymeric biomaterials due to high temperature and moisture that disrupts biochemical structures and causes coagulation of proteins.[녀, 168]

Materials require special permeable packages to ensure steam reaches all surfaces.[42]

Can sterilize liquids.[느]

More effective than dry heat against prions.[42]

Used in both industry and clinical settings.

\section{Ionizing radiation}

Gamma $(\gamma)$ radiation from ${ }^{60} \mathrm{Co}$
Effective against spore forming bacteria.

Radiation doses $\leq 25 \mathrm{kGy}$ do not alter the mechanical performance of soft tissues.[169]

Suitable for heat and moisture sensitive materials.

Higher penetration $(50-80 \mathrm{~cm}) \cdot[\underline{45}$, $\underline{170}$
Predominantly only available in industrial and research centers.[42]

High capital cost for installation and maintenance.

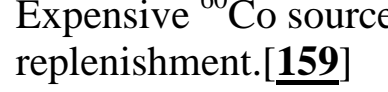

Unsuitable for small tissue batch producers. 
Dose rate approximately $10 \mathrm{kGy} / \mathrm{h}$. Requires high doses to deactivate viruses $(89 \mathrm{kGy})$.

Immediate release after processing. Higher doses than $35 \mathrm{kGy}$ cause tissue damage.[푸]

No need for permeable packaging. Causes crosslinking and/or peptide chain breakage. $[\underline{53,168}]$

Leaves no chemical residues or radioactive substances. $[\underline{\mathbf{1 6 8}, \mathbf{1 7 1}}$ 172]

Cost-effective compared to EtO.[170]

Not appropriate for viral or prion infected tissue.[프]

High doses required to eliminate endotoxins.[누]

Electron (e-beam) radiation Can sterilize heat and moisture sensitive materials, and generally more compatible than $\gamma$.[42]

High equipment and operational cost.[174]

Doses up to $34 \mathrm{kGy}$ are less harmful on soft tissues.[173]

Higher doses than $35 \mathrm{kGy}$ damaging to tissues.

High dose rate (quick sterilization dose delivery within minutes).[프]

High electric consumption.[프]

No need for permeable packaging. Not appropriate virally infected human donated tissue grafts.[프]

Immediate release after processing. $\quad$ Low penetration depth $(5-8 \mathrm{~cm})$. $[\underline{43}$, $\underline{170}]$

No chemical residues or

Not recommended for high density 
radioactive substances. $[\underline{\mathbf{1 6 8}, \mathbf{1 7 1}}$ 172]

Cost effective compared to EtO.[170]

\section{Chemical}

Ethylene oxide gas (EtO)
Reliable and effective sterilization.[175]

Efficient bactericidal, sporicidal, and virucidal activity.[1]

Rapidly deactivates hepatitis B and HIV-1 viruses.[177]

Causes less damage to extracellular matrix than $\gamma$, e-beam, and glutaraldehyde methods.[푸]

Suitable for bulk sterilization. materials.

Acceptable sterilization doses are not effective against prions.

Ineffective against endotoxins.

Only available and suitable for largescale usage.

High costs for small scale use.

Lengthy sterilization process. $[\underline{\mathbf{1 6 8}, \mathbf{1 7 8}}]$

Requires special gas-permeable packaging.[33]

Recognized as a toxic waste by the Environmental Protection Agency (EPA).[60, 168, 178-180]

Potentially carcinogenic. $[\underline{60,181,182}]$

Process monitoring is more complex than radiation, needs to control several parameters.[42, 183]

Flammable and explosive.[184] 

Leaves toxic residues on sterilized
materials.[투요

Causes potential damage to tissues. $[\underline{60}$, $\underline{61,183,185}$ ]

Not recommended for sterilization of tissue allografts.[180, 185]

Danger to facility workers.[툐

Ineffective against prions.[34]

\section{1}

272 Ionizing radiation sterilization at moderate doses is used at large-scale for medical supplies

273 and synthetic prostheses, but there are concerns regarding their destructive effects on TBTMs

274 at higher doses. $\gamma$ and e-beam radiation are widely applied for tissue sterilization including

275 AM.[54-57] Twenty-five kGy from both e-beam and $\gamma$ sources has been internationally

276 accepted as a guaranteed dose, however, the International Atomic Energy Agency (IAEA)

277 standards[ $\underline{58}]$ recommend a dose of below $25 \mathrm{kGy}$.[30] Conversely, concerns regarding viral

278 transmission via allografts from deceased donors potentially infected with HIV/HCV/HBV

279 justify higher doses (e.g., $35 \mathrm{kGy}$ ).[4] Debates regarding optimal sterilization dose reflect

280 concerns regarding unacceptable structural damage or physicochemical changes caused by

281 high radiation doses $[\underline{45,59}]$ and irradiation cost, especially for small tissue manufacturers, is

282 an additional issue.

283 Chemical sterilization, such as EtO, has toxicity concerns due to high oxidative stresses of

284 free radicals and residues, time-consuming processes, expense, and difficult operational

285 requirements. EtO sterilization unavoidably leaves residuals such as ethylene chlorohydrin

286 and ethylene glycol on treated products,[우 $]$ limiting the functionality of biological

287 tissues.[61] Other chemical sterilization methods, occasionally used for TBTM; are rarely

288 regarded as terminal sterilization due to technical, safety, or biocompatibility barriers. Super

289 critical carbon dioxide $\left(\mathrm{SCCO}_{2}\right),[\underline{62}]$ characterized by its efficacy against spores, penetration,

290 and biomaterial compatibility,[느-65] is reported to cause damage to materials, leaves 
291 residues, and is ineffective against endotoxins.[53, 66] Vaporized peracetic acid (PAA) gas

292 plasma, has been proven to have broad germicidal action over short-time periods,[67] and is

293 compatible with most collagenous materials and tissues.[ㅎ8-70] However, PAA has time and

294 cost constraints[ $[\mathbf{7 1}$ ] and additionally, PAA sterilized ophthalmic instruments have been

295 documented to cause serious ophthalmic and skin damage with contact, leading to withdrawal

296 from the market place. $[\underline{64,72,73}]$ Similarly, vaporized hydrogen peroxide $\left(\mathrm{H}_{2} \mathrm{O}_{2}\right)$ gas plasma

297 is used efficiently for TBTM sterilization and is FDA approved.[ㄴ, 75] However, it has

298 problems regarding adverse reactions with the functional properties of the tissue and medical

299 materials.[주, 77] Glutaraldehyde sterilization protocols are relatively inexpensive, effective

300 against most bacteria and viruses, but limited by long process cycles and toxicity to recipient

301 tissues and potentially crosslinking effects.[뚜]

302

3035 COLD ATMOSPHERIC PRESSURE GAS PLASMA FOR TERMINAL

304 STERILIZATION

305 Plasma $\underline{3}$ has been widely investigated for medical applications in recent years. Progressive

306 findings regarding the role of plasma in the deactivation and elimination of biological

307 contamination demonstrates the potential for this technology to overcome the drawbacks of

308 conventional sterilization methods of heat sensitive materials including TBTM.

\subsection{Thermal and non-thermal plasmas}

311 Plasmas at atmospheric pressure can be classified in terms of temperature into two categories, thermal $[\underline{79,80}]$ and non-thermal. $[\underline{\mathbf{8 1 - 8 3}}]$ In thermal plasma, the charged particles, neutral electrons, and heavy particles all have the same high temperatures (in thermodynamic equilibrium with the surrounding temperature) and are almost fully ionized; while, in the nonthermal plasma the temperature of gas, atoms, and molecules remains low[ [84] because of the slight ionization of the used gas,[푸 $]$ with only electrons at high temperature. Due to this

317 variation of the constituent's temperature, non-thermal plasma is also termed non-equilibrium 318 plasma. $[\underline{\mathbf{8 5}, \mathbf{8 6}}]$ 
323 Given that thermal plasma produces high gas temperature, non-thermal “cold” plasma is

324 much more suitable as an emerging sterilization method, $[\underline{\mathbf{8 0}, \mathbf{8 5}}]$ for inactivation of microbial

325 loads on human tissues and heat sensitive surfaces.[ㅈ] Furthermore, cold plasma can be

326 produced at low pressures, under vacuum, but for practicality and economic reasons, it is

327 more convenient and cost-effective when generated at atmospheric pressure and therefore

328 called cold atmospheric-pressure plasma (CAP).[무]

329 CAP is obtained by exposing gas flow (either air, or noble gases such as oxygen, nitrogen,

330 argon, or helium) to a high electric field which partially ionizes the gas atoms producing a

331 sustained plasma. This plasma contains a collection of excited electrons, negative and

332 positive ions, excited gas species, for example, $\mathrm{O}, \mathrm{O}_{2}^{*}, \mathrm{O}_{3}, \mathrm{OH}^{*}$, reactive oxygen species

333 (ROS), $\mathrm{NO}$ and $\mathrm{NO}_{2}$ reactive nitrogen species (RNS), free radicals, and UV-photons at

334 different wavelengths. [요 These nontoxic gases become germicidal only after the plasma is

335 ignited, since they are not biocidal on their own.[요] Concentration of produced plasma

336 agents (i.e., ROS, RNS, UV, free radicals, charged particles) depends on the operation

337 parameters of the plasma source; namely loaded gas, gas pressure, flow rate, electric voltage, 338 etc.

\subsection{CAP systems}

341 CAP can be provided by three different systems (Figure 1): (i) direct plasma, known as the

342 dielectric barrier discharge (DBD) system. By design, the DBD system safely uses the

343 material to be sterilized as a grounded electrode, which the current flows through, while the

344 other electrode is connected to a high voltage; air is utilized as the operating gas, and the

345 distance between plasma source tip and the object is a few millimeters[푹; (ii) "indirect

346 plasma," also known as atmospheric pressure plasma jet, which is deployed by a plasma

347 needle/pen (narrow focused jet) or plasma torch systems which have broader streams and

348 cover larger surface areas.[90] These devices generate plasma between two electrodes,

349 transferred through a gas flow to the object to be treated, the distance between the object and

350 the device ranges from millimeters to centimeters. The reactive species are generated by

351 igniting plasma in an operating gas such as air, or by helium or argon plasmas in an

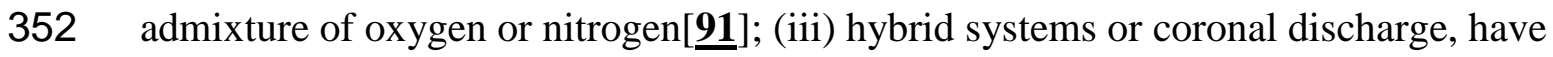

353 characteristics of both direct and indirect plasmas.[풍 92] 


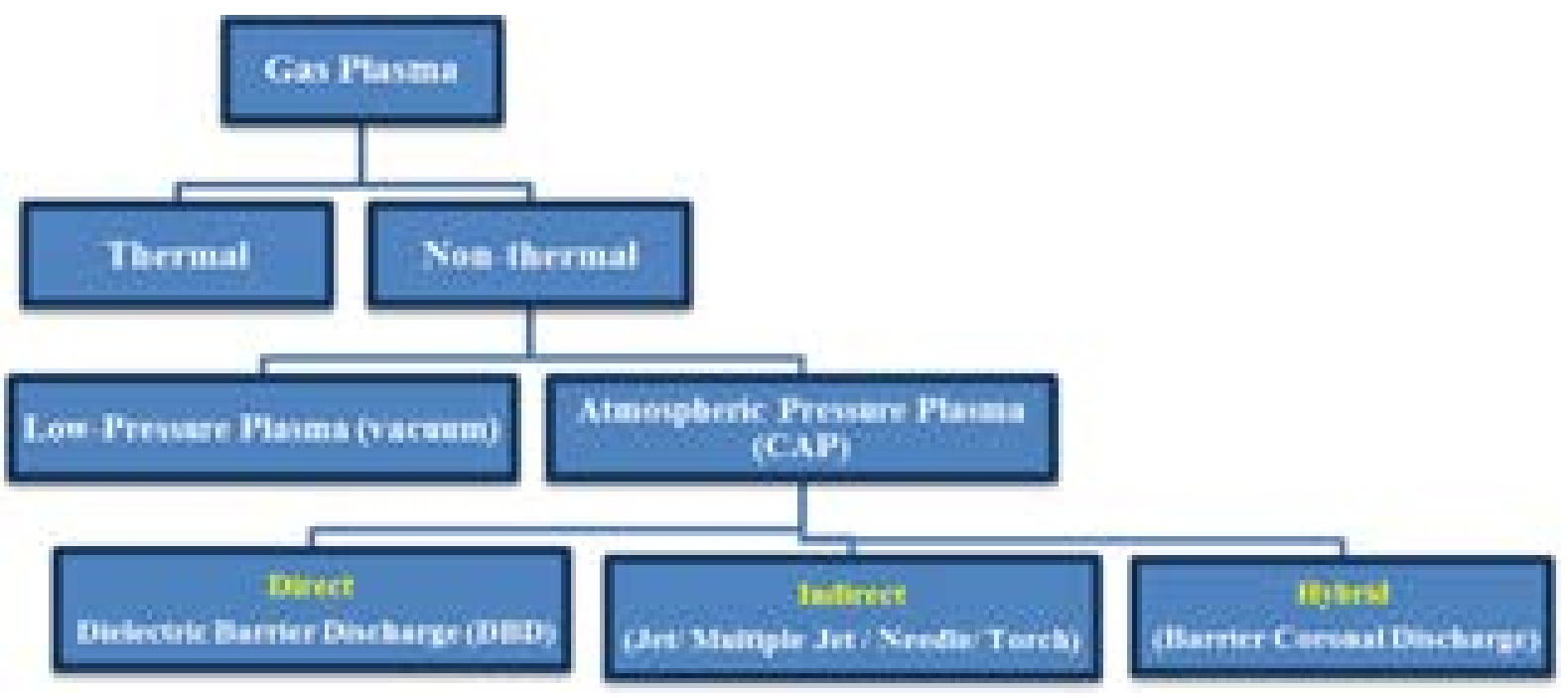

355 Figure 1. Schematic diagram showing non-thermal, cold atmospheric pressure plasma system 356 types

\subsection{Mechanisms of microbial inactivation by CAP}

359 CAP technologies have been used effectively to eliminate microorganisms on living tissues in several clinical applications, $[\underline{\mathbf{8}, 79,93-100}]$ including inactivation and eradication of fungi, and vegetative and spore-forming bacteria. $[\underline{\mathbf{8 5}, \mathbf{8 8}, \mathbf{1 0 1}}]$ The microbial inactivation effect of CAP can be attained by direct exposure to both the ignited plasma discharge products such as ROS, RNS, UV radiation, or indirectly through the long-lived species that are capable to reach the treated substrate without the electric field effect.[우 $]$ Generally, decontamination through plasma treatment is accomplished via oxidative stress arisen from synergetic actions of plasma discharge products. $[\underline{\mathbf{8 7}, \mathbf{1 0 2}}]$

367 The specific plasma agent responsible for the mechanism of CAP killing is not clearly corroborated in literature $[\underline{\mathbf{7}, \mathbf{8 8}}]$; although CAP is proven to be damaging to bacterial cell walls, primarily due to ROS and RNS.[103] These charged particles have sufficient ability to induce high oxidative stress which cause damage in microbial cells via fast direct interactions.[요 It has been postulated that the accumulation of plasma charged particles

372 over the bacterial cell membrane causes membrane rupture through electrostatic

373 disruption[104]; or that the reactive species permeabilize and penetrate the cell walls before reacting with DNA via complex mechanisms.[105] Membrane damage through lipid

375 peroxidation is another major cause of bacterial death by CAP. The effect by heat and UV is 376 argued to be indirect or negligible.[106, 107] However, CAP's microbicidal action produced 
by various plasma sources are reported to target viable cellular components such cell membrane, protein, and DNA. The effect of CAP is believed overwhelming the DNA repair mechanisms of the bacterial cells.[]]

5.5 Effects of CAP on vegetative and spore-forming bacteria

Plasma agents destroy different microbial entities irrespective of their molecular defense mechanisms. Examples reported of CAP capability for decontaminating multidrug resistant

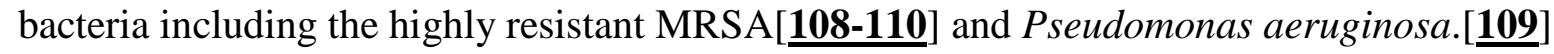
Notably, CAP is also effective on the sterilization resistant Deinococcus radiodurans ( $D$. radiodurans) bacteria.[111] Less resistant vegetative bacteria have also been tested against the antimicrobial activity of CAP, and were eliminated with different degrees of survival, including gram-negative: E. coli,[110, 112, 113] Salmonella typhimurium,[114] and gram-

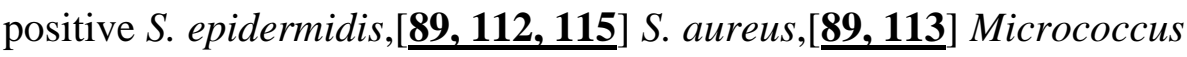

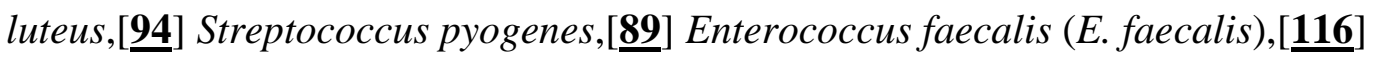
and Enterococcus faecium.[89] Gram-negative bacteria are more susceptible to gas plasma treatments than gram-positive $[\underline{103,117}]$ and differences in susceptibility are thought to be due to variation in the thickness of the peptidoglycan murein layer in the bacterial cell wall. $[\underline{85,103}]$

Skin floral bacteria S. epidermidis is of particular importance in sterilization of TBTM given its frequent association with contamination from procurement and processing sites. It is normally found in the hair follicle where it is protected from antiseptics. CAP penetration has the capacity to reach deep into hair follicles[118] and disinfect bacteria by 94\%.[119] Grampositive skin flora Propionibacterium acnes (P. acnes), reported to cause post-transplantation and implantation infection, are also effectively sterilized by CAP even in protected

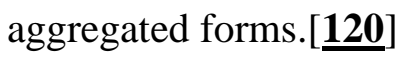

402 Spore-forming bacteria are typically resistant to many established sterilization protocols, and 403 are often used as a model organism for sterilization verification. Studies have demonstrated 404 CAP efficacy against bacterial spores, including: Bacillus subtilis (B. subtillis), C. 405 difficile, Bacillus atrophaeus (B. atrophaeus), Bacillus safensis (B. safensis), Bacillus megaterium (B. megaterium), B. megaterium 2c1, and Bacillus thuringiensis (B. thuringiensis)

407 E24.[121, 122] Studies have shown CAP has effective sporicidal action even in humid 408 conditions, $[\underline{\mathbf{1 2 3}, \mathbf{1 2 4}}]$ when spores are stacked together or covered by debris. 
411 TBTM manufactured in a sterile environment using cGTP protocols are unlikely to have

412 resistant contamination such as endotoxins, prions, viruses, and biofilms unless a pre-

413 processing infection has occurred. Efficient sterilization should be able to inactivate all forms

414 of disease causing contamination. The advantage of CAP sterilization compared to traditional

415 methods is its powerful efficacy to eliminate resistant contamination and removal through its

416 etching action, which is highly dependent upon applied plasma source. For instance, plasma

417 jets have more etching capabilities than DBD systems. The plasma density, gas mixture, and

418 radical content are important parameters in etching of protein residues from treated surface

419 by chemical degradation and volatilization mechanisms.[125] CAP has been demonstrated to

420 be effective for inactivation of LPS endotoxin removal from treated surfaces within

421 minutes.[126, 127] Similarly, it has been shown that CAP is efficient in removing amyloid

422 fibril aggregates (protein structure mimics prion) from a surfaces, and that aggregates outside

423 the plasma diameter were degraded, while those within the plasma focus were consistently

424 removed.[128] The use of a CAP system with a negative corona discharge has been shown to

425 have a significant effect on prions and may reduce the infectivity of prion particles by several

426 orders of magnitude.[129] This was believed to be mediated by the generated reactive

427 particles. Additionally in this study, the source of CAP had different effects on the viability

428 of brain cells; a positive streamer discharge killed the cells, whereas point-to-point, cometary,

429 and negative corona discharges did not result in a loss of cell viability. This indicates that the

430 discharge configuration is an important parameter to consider when sterilizing viable tissues

431 with CAP.

432 TBTM contaminants such as the anaerobic gram-positive P. acnes and Staphylococcus have

433 been proven to form in vivo and in vitro biofilms, and develop resistance to gentamicin-

434 loaded implants for orthopedic surgery,[43] causing biomaterial/prosthesis transplant

435 infection and failure.[130] Biofilms of $P$. acnes bacteria have been found to be considerably

436 inactivated by two types of plasma jet over short-time periods.[120] Biofilms of MRSA, $S$.

437 epidermidis, S. aureus, and E. coli are also removed by CAP treatment.[12] Similarly, CAP

438 have efficiently removed biofilms of antifungal resistant Candida albicans (C. albicans).[131]

439 This effect can potentially be enhanced by adding oxygen to the plasma discharge.[132]

440 Studies have shown that viruses can be eliminated by CAP, due to the destruction of the

441 protein coat, rather than a direct effect on viral DNA.[133] 
442 Several factors may affect the dose or the exposure time required to achieve sterilization.

443 These factors are related to the plasma device operational conditions or the microorganism

444 conditions before and after exposure, e.g., bacterial species, bacterial culture age (growth

445 phase), bacterial medium during, and post-treatment.[134] The eradicating effect of CAP on

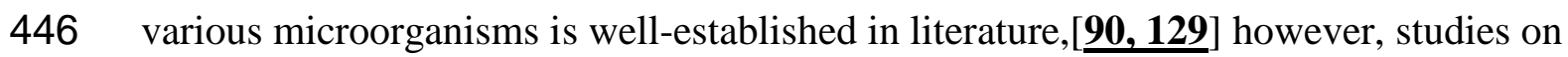

447 sterilization and removal of biological non-living disease causing agents would have a

448 promising medical applications. $[\underline{\mathbf{1 3}, \mathbf{1 2 9}}]$ However, CAP system variation, the flexibility of

449 utilizing variable operational conditions along with the different applications have resulted in

450 complication when comparing the literature findings. Table $\underline{2}$ shows examples of the

451 sensitivity of microorganisms of medical importance and other biological contaminants

452 resistant to sterilization, treated with different CAP devices under various experimental

453 conditions, with differences in exposure times and contamination reductions. CAP device

454 specifications and the applied dose were omitted due to the aforementioned plasma delivery

455 complexities. Often, the time required to inactivate or sterilize the microbial/biological

456 contaminations is much shorter than those applied in other established sterilization methods

457 regardless of the CAP system used. To achieve SAL $10^{-6}$ sterilization, exposure duration

458 (plasma dose) may be extended. Therefore, it is important to have information on the level of

459 initial material contamination if CAP is chosen as a sterilization protocol. It can be difficult to

460 contrast and compare CAP efficacy on biological contamination due to the variability in CAP

461 parameters and systems; however, this does not indicate that CAP is ineffective.

462 Table 2. Examples of susceptibility of vegetative bacteria, fungi, bacterial spores, endotoxins, 463 prions, and biofilm to CAP treatment 


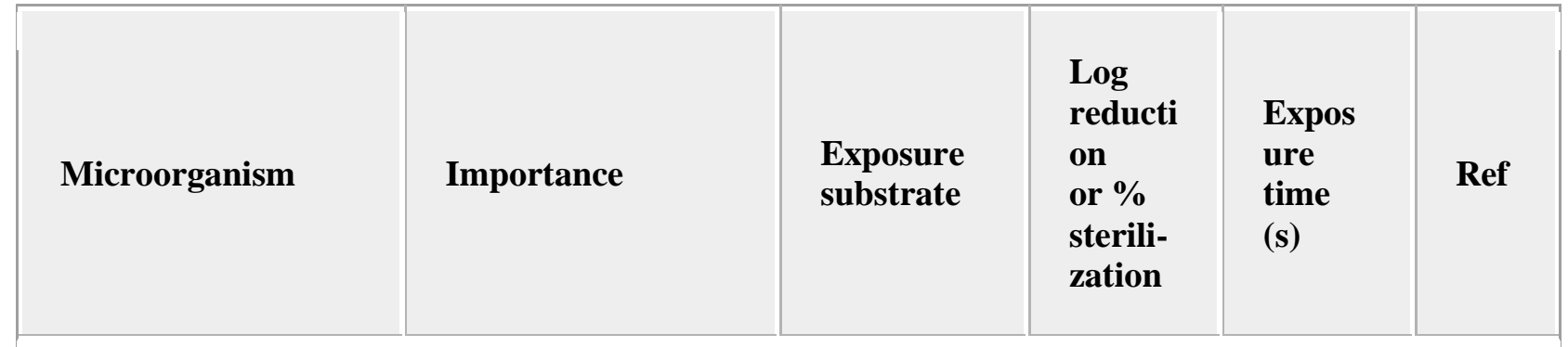

aKCTC, Korean Collection for Type Cultures, Korea.

bATCC, American Type Culture Collection, USA.

cDSM, Leibnitz Institute DSMZ-German Collection of Microorganism and Cell Cultures, Germany.

dNA, not available.

Vegetative bacteria (gram-negative)

E. coli

Clinical pathogen

Agar

medium

$\underline{12}$

plates

E. coli

Clinical pathogen

Glass

$100 \%$

$[\underline{18}$

slides

E.

Clinical pathogen

Thin glass covers

$[\underline{12}$

coli KCTCa 1039

$10 \log$

$100 \% \quad 60$

$\begin{array}{llllll}\begin{array}{l}\text { E. coli O157:H7 } \\ \text { (C9490) }\end{array} & \text { Foodborne } & \text { Dry } & 1.34 & 20 & {[\underline{\mathbf{1 8}}} \\ & \text { pathogens } & \text { almonds } & \log & & \underline{\mathbf{8}}]\end{array}$

E. coli

O157:H7 (ATCC $\underline{b}$

35150)

E. coli O157:H7

(ATCC 43894)

Salmonella

anatumF4317 


\begin{tabular}{|c|c|c|c|c|c|}
\hline Microorganism & Importance & $\begin{array}{l}\text { Exposure } \\
\text { substrate }\end{array}$ & $\begin{array}{l}\text { Log } \\
\text { reducti } \\
\text { on } \\
\text { or } \% \\
\text { sterili- } \\
\text { zation }\end{array}$ & $\begin{array}{l}\text { Expos } \\
\text { ure } \\
\text { time } \\
\text { (s) }\end{array}$ & Ref \\
\hline \multicolumn{6}{|l|}{$\begin{array}{l}\text { Salmonella } \\
\text { stanleyH0558 }\end{array}$} \\
\hline \multicolumn{6}{|l|}{$\begin{array}{l}\text { Salmonella } \\
\text { enteritidisPT30 }\end{array}$} \\
\hline \multicolumn{6}{|c|}{ Vegetative bacteria (gram-positive) } \\
\hline $\begin{array}{l}\text { P. acnes KCTC } \\
3314\end{array}$ & Skin flora & $\begin{array}{l}\text { Coated } \\
\text { glass } \\
\text { slides }\end{array}$ & $7 \log$ & 600 & $\begin{array}{l}{[\underline{12}} \\
\underline{\mathbf{0}}]\end{array}$ \\
\hline D. radiodurans & $\begin{array}{l}\text { Radiation, drying, } \\
\text { and oxidizing } \\
\text { agent resistant }\end{array}$ & $\begin{array}{l}\text { Aluminu } \\
\text { m discs }\end{array}$ & $3 \log$ & 1800 & $\begin{array}{l}{[\underline{12}} \\
\underline{2}]\end{array}$ \\
\hline $\begin{array}{l}\text { Lactobacillus } \\
\text { acidophilus }\end{array}$ & $\begin{array}{l}\text { Oral caries } \\
\text { producing bacteria }\end{array}$ & $\begin{array}{l}\text { Hydroxya } \\
\text {-patite }\end{array}$ & $\begin{array}{l}1.5-2 \\
\log \end{array}$ & 6 & $\begin{array}{l}{[\underline{18}} \\
\underline{9}]\end{array}$ \\
\hline \multicolumn{6}{|l|}{$\begin{array}{l}\text { Streptococcus } \\
\text { mutans }\end{array}$} \\
\hline $\begin{array}{l}\text { Listeria } \\
\text { innocua (ATCC } \\
\text { 33090) }\end{array}$ & $\begin{array}{l}\text { Non-pathogenic } \\
\text { surrogate for the } \\
\text { foodborne } \\
\text { pathogen monocyt } \\
\text { ogenes }\end{array}$ & $\begin{array}{l}\text { Chicken } \\
\text { meat and } \\
\text { skin }\end{array}$ & $3.3 \log$ & 480 & $\begin{array}{l}{[\underline{15}} \\
\underline{\mathbf{0}}]\end{array}$ \\
\hline Fungi & & & & & \\
\hline $\begin{array}{l}\text { C. } \\
\text { albicans (thickness } \\
\text { of } 10-20 \mathrm{~mm} \text { ) }\end{array}$ & Pathogenic fungus & $\begin{array}{l}\text { Polystyren } \\
\text { e wafers }\end{array}$ & $95 \%$ & 300 & $\begin{array}{l}{[\underline{13}} \\
\underline{2}]\end{array}$ \\
\hline
\end{tabular}




\begin{tabular}{|c|c|c|c|c|c|}
\hline Microorganism & Importance & $\begin{array}{l}\text { Exposure } \\
\text { substrate }\end{array}$ & $\begin{array}{l}\text { Log } \\
\text { reducti } \\
\text { on } \\
\text { or } \% \\
\text { sterili- } \\
\text { zation }\end{array}$ & $\begin{array}{l}\text { Expos } \\
\text { ure } \\
\text { time } \\
\text { (s) }\end{array}$ & Ref \\
\hline C. albicans & $\begin{array}{l}\text { Antifungal } \\
\text { resistant } \\
\text { (fluconazole- } \\
\text { resistance) }\end{array}$ & Air & $>90 \%$ & 600 & $\begin{array}{l}{[\underline{19}} \\
\underline{0}]\end{array}$ \\
\hline Candida krusei & & Water & $>90 \%$ & 60 & \\
\hline \multicolumn{6}{|l|}{ Candida glabrata } \\
\hline $\begin{array}{l}\text { Aspergillus } \\
\text { flavus (ATCC 327) }\end{array}$ & $\begin{array}{l}\text { Mycotoxin } \\
\text { producing food } \\
\text { contaminants }\end{array}$ & Hazelnuts & $\begin{array}{l}4.50 \\
\log \end{array}$ & 300 & $\underline{[19}$ \\
\hline $\begin{array}{l}\text { Aspergillus } \\
\text { parasiticus(ATCC } \\
\text { 1041) }\end{array}$ & & & $\begin{array}{l}4.19 \\
\log \end{array}$ & & \\
\hline $\begin{array}{l}\text { Aspergillus } \\
\text { parasiticus798 } \\
\text { TUBITAK-MAM }\end{array}$ & $\begin{array}{l}\text { Bio-indicator } \\
\text { fungus }\end{array}$ & $\begin{array}{l}\text { Vegetable } \\
\text { and } \\
\text { legumes } \\
\text { seed } \\
\text { surfaces }\end{array}$ & $3 \log$ & 900 & $\begin{array}{l}{[\underline{19}} \\
\underline{2}]\end{array}$ \\
\hline \multicolumn{6}{|l|}{$\begin{array}{l}\text { Penicillum MS198 } \\
2\end{array}$} \\
\hline \multicolumn{6}{|c|}{ Spore-forming bacteria } \\
\hline B. subtilis & $\begin{array}{l}\text { Sterilization } \\
\text { resistant }\end{array}$ & $\begin{array}{l}\text { Thin glass } \\
\text { covers }\end{array}$ & $10 \log$ & 24 & $\underline{[12}$ \\
\hline & & & $100 \%$ & 120 & \\
\hline
\end{tabular}




\begin{tabular}{|c|c|c|c|c|c|}
\hline Microorganism & Importance & $\begin{array}{l}\text { Exposure } \\
\text { substrate }\end{array}$ & $\begin{array}{l}\text { Log } \\
\text { reducti } \\
\text { on } \\
\text { or } \% \\
\text { sterili- } \\
\text { zation }\end{array}$ & $\begin{array}{l}\text { Expos } \\
\text { ure } \\
\text { time } \\
\text { (s) }\end{array}$ & Ref \\
\hline $\begin{array}{l}\text { B. } \\
\text { safensis, DSMc19 } \\
292 \mathrm{~T}\end{array}$ & $\begin{array}{l}\text { Sterilization } \\
\text { resistant }\end{array}$ & $\begin{array}{l}\text { Aluminu } \\
\text { m discs }\end{array}$ & $>6 \log$ & 3600 & $\begin{array}{l}{[\underline{12}} \\
\underline{2}]\end{array}$ \\
\hline $\begin{array}{l}\text { B. megaterium, } \\
\text { ATCC } 14581 T\end{array}$ & & & $100 \%$ & 5400 & \\
\hline \multicolumn{6}{|l|}{$\begin{array}{l}\text { B. } \\
\text { megaterium DSM } \\
30587 \text { (2c1) }\end{array}$} \\
\hline $\begin{array}{l}\text { B. } \\
\text { atrophaeus DSM6 } \\
75\end{array}$ & $\begin{array}{l}\text { Sterilization } \\
\text { resistant }\end{array}$ & $\begin{array}{l}\text { Aluminu } \\
\text { m discs }\end{array}$ & $>3 \log$ & 5400 & $\begin{array}{l}{[\underline{12}} \\
\underline{2}]\end{array}$ \\
\hline \multicolumn{6}{|l|}{$\begin{array}{l}B . \\
\text { thuringiensis DSM } \\
30879 \text { (E24) }\end{array}$} \\
\hline B. subtilis & $\begin{array}{l}\text { Sterilization } \\
\text { resistant }\end{array}$ & $\begin{array}{l}\text { Glass } \\
\text { slide and } \\
\text { aluminum } \\
\text { substrates }\end{array}$ & $\begin{array}{l}4 \text { log } \\
\text { (He } \\
\text { plasma } \\
\text { ) }\end{array}$ & $<600$ & $\frac{[19}{\underline{3}]}$ \\
\hline & & & $\begin{array}{l}8 \text { log } \\
\text { (air } \\
\text { plasma } \\
\text { ) }\end{array}$ & & \\
\hline B. atrophaeus & $\begin{array}{l}\text { Biological } \\
\text { indicator for } \\
\text { thermal } \\
\text { sterilization (heat } \\
\text { resistant) }\end{array}$ & $\begin{array}{l}\text { Commerci } \\
\text { al spore } \\
\text { strip }\end{array}$ & $\begin{array}{l}\geq 6 \\
\log 10\end{array}$ & 60 & $\frac{[12}{4]}$ \\
\hline
\end{tabular}




\begin{tabular}{|c|c|c|c|c|c|}
\hline Microorganism & Importance & $\begin{array}{l}\text { Exposure } \\
\text { substrate }\end{array}$ & $\begin{array}{l}\text { Log } \\
\text { reducti } \\
\text { on } \\
\text { or \% } \\
\text { sterili- } \\
\text { zation }\end{array}$ & $\begin{array}{l}\text { Expos } \\
\text { ure } \\
\text { time } \\
\text { (s) }\end{array}$ & Ref \\
\hline \multicolumn{6}{|l|}{ Endotoxins } \\
\hline $\begin{array}{l}\text { LPS from } E \text {. } \\
\text { Coli ATCC } 8739\end{array}$ & Pyrogen & $\begin{array}{l}\text { Glass } \\
\text { slides }\end{array}$ & $100 \%$ & 10 & $\underline{[18}$ \\
\hline \multicolumn{6}{|l|}{ Viruses } \\
\hline $\begin{array}{l}\text { Adenovirus, non- } \\
\text { enveloped double } \\
\text { stranded DNA } \\
\text { virus }\end{array}$ & $\begin{array}{l}\text { Human infectious } \\
\text { disease causing }\end{array}$ & $\begin{array}{l}\text { PBS } \\
\text { solution }\end{array}$ & $6 \log$ & 240 & $\underline{[13}$ \\
\hline $\begin{array}{l}\text { Bacteriophage } \\
\text { lambda ( } \lambda \text { phage })\end{array}$ & $\begin{array}{l}\text { Virus that infects } \\
\text { bacteria }\end{array}$ & Buffer & $6 \log$ & 20 & $\underline{[\mathbf{1 3}}$ \\
\hline $\begin{array}{l}\text { Bacteriophage } \\
\text { lambda ( } \lambda \text { phage) } \\
\text { C-17 (ATCC } \\
\text { 23724-B1) }\end{array}$ & $\begin{array}{l}\text { Virus that infects } \\
\text { bacteria }\end{array}$ & NA $\underline{d}$ & $\begin{array}{l}4-6 \\
\log \end{array}$ & 600 & $\underline{[19}$ \\
\hline \multicolumn{6}{|l|}{$\begin{array}{l}\text { Lytic } \\
\text { bacteriophage } \\
\text { (rambo; } \\
\text { microphage) }\end{array}$} \\
\hline $\begin{array}{l}\text { MS2 } \\
\text { bacteriophage } \\
\text { ATTC 15597-B1 }\end{array}$ & $\begin{array}{l}\text { Surrogate of } \\
\text { human enteric } \\
\text { viruses such as } \\
\text { norovirus that } \\
\text { causes infectious } \\
\text { gastroenteritis }\end{array}$ & $\begin{array}{l}\text { Phage } \\
\text { suspensio } \\
n\end{array}$ & $\begin{array}{l}4.98- \\
7.06 \\
\log \end{array}$ & 450 & $\begin{array}{l}{[\underline{19}} \\
\underline{5}]\end{array}$ \\
\hline $\begin{array}{l}\text { Influenza virus } \\
\text { type A (H5N2) }\end{array}$ & $\begin{array}{l}\text { Airborne } \\
\text { respiratory }\end{array}$ & $\begin{array}{l}\text { Viral } \\
\text { aerosol }\end{array}$ & $\begin{array}{l}4 \log \\
(99.20\end{array}$ & 180 & $\underline{[19}$ \\
\hline
\end{tabular}




\begin{tabular}{|c|c|c|c|c|c|}
\hline Microorganism & Importance & $\begin{array}{l}\text { Exposure } \\
\text { substrate }\end{array}$ & $\begin{array}{l}\text { Log } \\
\text { reducti } \\
\text { on } \\
\text { or \% } \\
\text { sterili- } \\
\text { zation }\end{array}$ & $\begin{array}{l}\text { Expos } \\
\text { ure } \\
\text { time } \\
\text { (s) }\end{array}$ & Ref \\
\hline & pathogen & $\begin{array}{l}\text { suspensio } \\
\mathrm{n}\end{array}$ & $\%)$ & & \\
\hline $\begin{array}{l}\text { Human } \\
\text { parainfluenza virus } \\
\text { type } 3 \text { strain C-243 } \\
\text { ATCC VR-93 }\end{array}$ & & & $\begin{array}{l}6.5 \log \\
(99.22 \\
\%)\end{array}$ & & \\
\hline $\begin{array}{l}\text { Respiratory } \\
\text { syncytial virus-A } \\
\text { ATCC VR-26 }\end{array}$ & & & $\begin{array}{l}3.8 \log \\
(99.00 \\
\%)\end{array}$ & & \\
\hline Prions & & & & & \\
\hline $\begin{array}{l}\text { Scrapie (Rocky } \\
\text { Mountain } \\
\text { Laboratory strain, } \\
\text { RML5) }\end{array}$ & $\begin{array}{l}\text { Surrogate of } \\
\text { human prion }\end{array}$ & $\begin{array}{l}1 \% \text { mouse } \\
\text { brain in } \\
\text { PBS } \\
\text { solution }\end{array}$ & $100 \%$ & $\begin{array}{l}600- \\
1200\end{array}$ & $\begin{array}{l}{[\underline{12}} \\
\underline{9}]\end{array}$ \\
\hline Biofilm & & & & & \\
\hline $\begin{array}{l}P . \\
\text { aeruginosa SG81 }\end{array}$ & Clinical pathogen & $\begin{array}{l}\text { Polycarbo } \\
\text { nate discs. }\end{array}$ & $\begin{array}{l}4.83 \\
\log \end{array}$ & 300 & $\underline{[11}$ \\
\hline \multirow{3}{*}{$\begin{array}{l}\text { S. } \\
\text { epidermidis RP62 } \\
\text { A }\end{array}$} & & & $\begin{array}{l}7.11 \\
\log \end{array}$ & 600 & \multirow{3}{*}{$\begin{array}{l}{[\underline{11}} \\
\underline{7}]\end{array}$} \\
\hline & Skin flora & $\begin{array}{l}\text { Polycarbo } \\
\text { nate discs }\end{array}$ & $\begin{array}{l}2.77 \\
\log \end{array}$ & 300 & \\
\hline & & & $\begin{array}{l}3.38 \\
\log \end{array}$ & 600 & \\
\hline
\end{tabular}




\begin{tabular}{|c|c|c|c|c|c|}
\hline Microorganism & Importance & $\begin{array}{l}\text { Exposure } \\
\text { substrate }\end{array}$ & $\begin{array}{l}\text { Log } \\
\text { reducti } \\
\text { on } \\
\text { or } \% \\
\text { sterili- } \\
\text { zation }\end{array}$ & $\begin{array}{l}\text { Expos } \\
\text { ure } \\
\text { time } \\
\text { (s) }\end{array}$ & Ref \\
\hline $\begin{array}{l}\text { Salmonella } \\
\text { enterica serovar } \\
\text { typhimurium }\end{array}$ & Clinical pathogens & Lettuce & $5 \log$ & 300 & $\frac{[19}{7]}$ \\
\hline \multicolumn{6}{|l|}{$\begin{array}{l}\text { Listeria } \\
\text { monocytogenes }\end{array}$} \\
\hline \multicolumn{6}{|l|}{ E. coli } \\
\hline \multicolumn{6}{|l|}{ E. faecalis } \\
\hline C. albicans & Clinical pathogen & $\begin{array}{l}\text { Inanimate } \\
\text { surface }\end{array}$ & $6 \log$ & 240 & {$[\underline{13}$} \\
\hline
\end{tabular}

$467 \quad 5.7$ Use of CAP for TBTM sterilization

468 CAP has been evaluated as a safe and efficient procedure for decontamination of skin wounds, 469 ulcers, and infected tissues in patients, and there are commercially available products such as

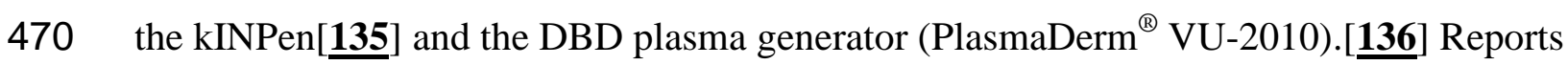

471 often emphasize the biocompatibility of plasma treatment on viable cells and tissues,

472 including ocular surface tissues.[100, 137-139] These effects are deleterious to microbial

473 contamination, but have thus far not been proved to induce necrotic, apoptotic, or

474 morphological changes in surrounding tissues. Furthermore, no significant effects on living

475 cell viability were reported.[110] In other studies, a slight reduction in viability through

476 necrosis of in vitro culture of mucosal cells was observed, however, no mutagenic effects

477 were observed.[135, 140] The reason CAP mechanisms are generally harmless to human cells

478 and tissue is attributed to CAP's superficial penetration, $[\underline{\mathbf{1 2 6}, \mathbf{1 4 1}}]$ and potentially that

479 multicellular eukaryotic tissues have more complicated mechanisms to enable survival of

480 oxidative stresses introduced by plasma agents, than prokaryotic cells.[142] Limited 
penetration could be an obstacle to CAP sterilization of TBTM with thick, heterogeneous size,

482 and architecture such as bone graft materials.[141] However, dried, thin, soft tissues such as

483 skin, facia, dura mater, AM, tendons, and laminate of cartilage and bone are all candidates for

484 CAP sterilization.[143] The defined advantages and disadvantages of CAP sterilization of

485 TBTM are listed in Table $\underline{3}$.

486

487 Table 3. Advantages and disadvantages of CAP sterilization of TBTM
Advantages
Disadvantages

Biocompatible with viable and non-viable

Methods not yet validated.

tissues.

No toxic chemical residue left on treated

Low penetration power so may be not object.[135]

suitable for thick TBTM materials.[141]

Shorter exposure time than established

Difficult to apply to packaged materials.

sterilization methods (seconds to minutes).

No toxic effects to operators and the environment.[198]

Not validated as terminal sterilization that offers SAL of $10^{-6}$.

Can remove bacterial cells and viruses from sterilized surfaces.

Many parameters (e.g., loaded gas, gas pressure, flow rate, voltage, exposure time, and sample distance) need to be controlled to get the desired capacity of charged species.

Effective on endotoxins, prions and bacterial, and fungal biofilms.[131]

Delivers uniform treatment to uneven surfaces of biological materials.[199]

CAP gas capable of reaching confined and narrow spaces.[표

Microorganism resistance to CAP is unlikely to 
Advantages

occur.[105]

Inexpensive.[200]

Can be used portably or in smaller scale (such

as in laminar flow hoods and isolators).[200]

\section{Disadvantages}

490 At the time of this review, there were no studies available evaluating CAP for sterilization of non-viable TBTM. However, if we consider non-viable AM as an example, a number of

492 factors should be considered when optimizing CAP specifically, tissue thickness, treatment area, surface morphology, probable type and count of contamination, and whether sterilization will occur before or after packaging.

A reliable sterilization method must have sufficient penetration capability. Studies have demonstrated that CAP delivers ROS in the range of 150-1500 $\mu \mathrm{m}[\underline{\mathbf{1 4 4}}]$ when employed on a tissue-equivalent material and at over $5000 \mu \mathrm{m}$ for agarose gels.[100] For intact viable skin, reactive species can penetrate up to $10 \mu \mathrm{m}$ depth.[135] The penetration of $\mathrm{H}_{2} \mathrm{O}_{2}$ produced by

499 CAP into euthanized rat skin and chicken breasts was shown to go up to $4000 \mu \mathrm{m}$.[145]

500 Furthermore, experiments on polyester fabric materials assert that the distance from plasma

501 nozzle to substrate, exposure time, and thickness of substrate, have an effect on plasma 502 penetration, yet suggests longer exposure time renders a sufficient amount of reactive species 503 accumulating on one side to diffuse to the other side of the porous material.[146, 147]

504 Moreover, it has been demonstrated that nitric oxide (NO) generated by topical application of 505 DBD over a human skin and reconstructed epidermiswere safe on living tissue and able to 506 penetrate and cause changes in microcirculation up to $6000-8000 \mu \mathrm{m}$ on treated skin

507 areas.[148] Dried AM with a thickness of approximately $20 \mu \mathrm{m}[\underline{\mathbf{1 4 9}}]$ will therefore lie within 508 the penetration range of CAP and should not require lengthy exposure times.

509 Surface topography of treated tissue present challenges in sterilization, as changes can occur 510 during chemical or mechanical processing, creating rough surfaces and microgrooves where 511 microorganisms can reside and proliferate. Tissue surface irregularity enables contaminant 
512 bacteria to migrate from the surface into the tissue, protecting it from the biocidal effect of

513 sterilization.[150] There are natural intercellular microholes on AM epithelial surface

514 (Figure 2A and B), which have been proven to allow gas transmission through dried and

515 cryopreserved AM upon transplantation.[151, 152] These microholes are impermeable to

516 bacteria such as E. coli, Pseudomonas, Klebsiella, and Staphylococcus.[153] CAP can easily

517 reach narrow, confined spaces, and microgrooves on surfaces.[1] and mobility of plasma gas

518 can allow for treatment of microspaces.[122, 154] Recent studies reported CAP efficacy in

519 reducing microbial contamination adhered to rough surfaces of chicken skin,[150] titanium

520 implant surfaces, [155] and root canals, especially in dry state conditions.[156] This supports

521 the appropriate use of CAP for sterilization of dry AM with a comparably soft homogenous

522 surface (Figure $2 \mathrm{~A}$ and $\mathrm{C}$ ).

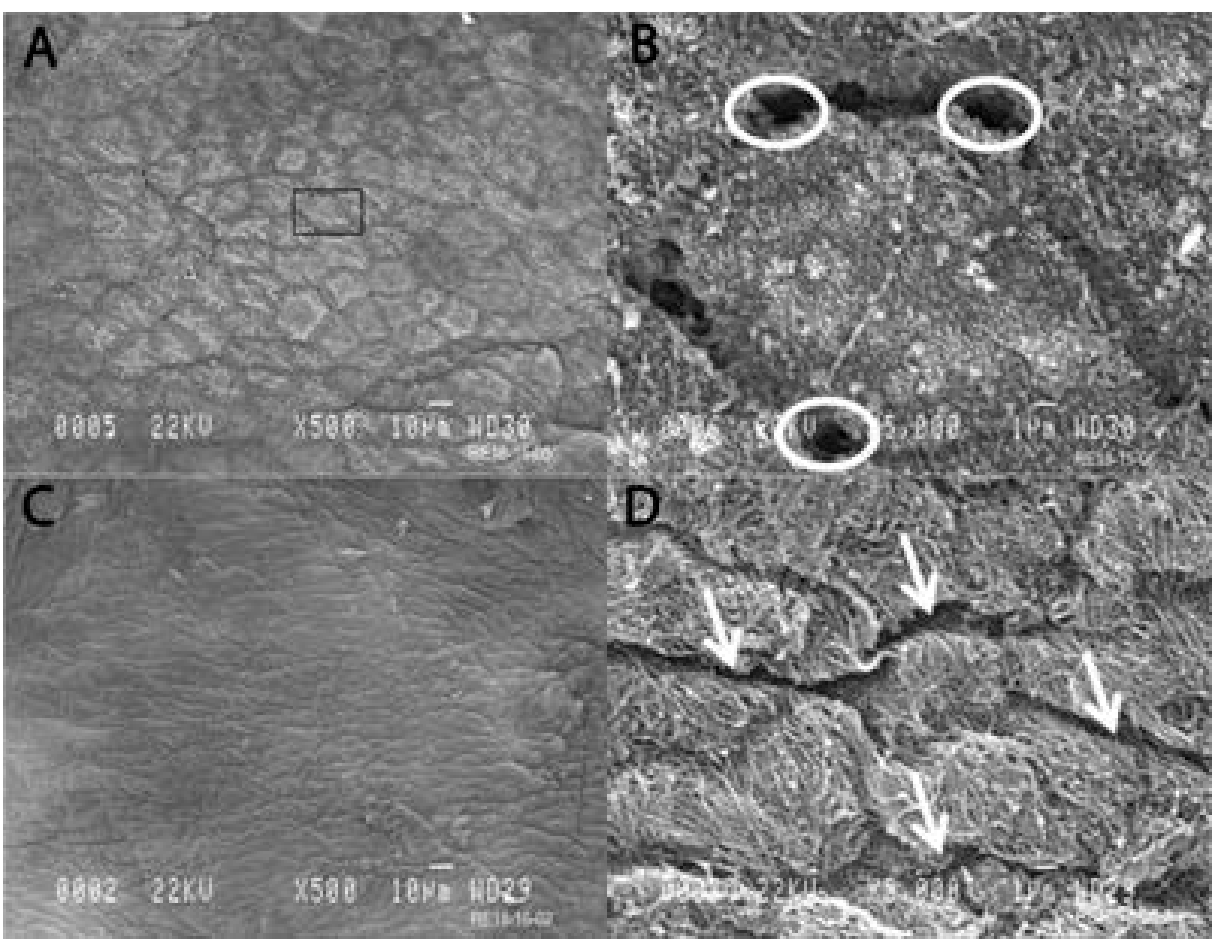

524 Figure 2. Scanning electron microscopy image of dried AM (A and B - epithelial side; C and

525 D - stromal side). (A) Intact polygonal epithelial surface cells with occasional intercellular

526 spaces (scale bar: $10 \mu \mathrm{m}$ ). (B) Box in (A) magnified to show distinct natural intracellular

527 microholes (white circles) around the cell (scale bar: $1 \mu \mathrm{m}$ ). (C) Smooth regular stromal

528 surface of AM (scale bar: $10 \mu \mathrm{m}$ ). (D) Collagen fibrils on the stromal side with tiny

529 microgrooves (white arrows), scale bar: $1 \mu \mathrm{m}$ )

530

531 Additionally, CAP treatment of large tissues requires a plasma source capable of delivering

532 plasma components over wider surface areas. Single CAP jets are limited to a few 
533 millimeters, for example, $25 \mathrm{~mm}^{2}$,[157] thus are unsuitable, but micro-discharge plasma

534 devices have been used effectively for biofilm treatment on a $177 \mathrm{~cm}^{2}$ surface area.[131]

535 Plasma torches are able to treat areas of approximately $25 \mathrm{~cm}^{2}$ and DBD and jet torches

536 appear to be favorable for large size membranous grafts[ $\underline{\mathbf{8 1}}]$ and have potential to be

537 developed to operate as a systemic scanning system for tissue materials with large surface

538 area. The area of AM grafts are generally $4-100 \mathrm{~cm}^{2}$, thus CAP systems could be developed

539 to accommodate this.

540 There are parameters related to the plasma system operational conditions that will affect use,

541 such as: the voltage, loaded gas, gas pressure, flow rate, exposure time, and sample distance

542 from plasma nozzle.[158, 159] The interplay of these parameters could yield sufficient

543 plasma density and composition, or conversely might change the treatment outcome; causing

544 inconsistency in sterilization cycles.[160] For instance, operational parameters such as ion

545 and UV flux, electric field, and gas flow might not have direct influence on the antibacterial

546 efficiency, while other factors related to the method and conditions of application such as

547 distance from the plasma nozzle and exposure time have a distinct influence on treatment

548 efficiency.[161]

549 An effective treatment that causes no damage to tissues requires a highly standardized, 550 balanced, and homogenous current discharge,[162] which can be attained by adjusting the 551 circuit, gas flow, and power supply parameters.[7] As varied modalities of CAP systems 552 have been used as decontamination tools on different biological substrates, such as human 553 skin and food products, it is possible to develop a CAP device that copes with thin non-viable 554 membranous tissue sealed in sterile packaging.

555 To maintain sterility of a manufactured TBTM, CAP should be applied after packaging or in556 package and sealed in a sterile environment. Use of CAP for in-package sterilization has been 557 tested effective against spores, used to decontaminate foods, and is compatible with some 558 packaging materials.[124, 163] DBD plasma configurations developed with efficient 559 sporicidal actions were found to safely fit several shapes of Tyvek packaging materials used 560 for sterile wrapping of medical instruments.[164] Different packaging materials including 561 polyethylene, polypropylene, and nylon loaded with microbial pathogens have shown no 562 change in the physical properties after treatment with low pressure plasma.[165] Recent 563 studies have shown that generating plasma inside a closed environment can prevent post564 packaging contamination of sterilized products.[퉅]

565 Another attractive advantage of CAP over conventional sterilization is cost-efficiency. Cold 566 plasma generators can be scaled-down as portable devices in a regular laboratory instrument 
567 size, for use on the bench, which suits application in small-scale tissue production.[] $]$ Close 568 proximity to tissue preparation site can potentially minimize cost of logistics and are not as

569 complex as performing terminal sterilization away from the production site.

570 Direct or indirect CAP systems may be appropriate for AM sterilization, as they can be

571 operated at atmospheric pressure and at nearly ambient temperature,[167] can deliver large

572 quantities of active species with sufficient penetration power of plasma agents,[요 $]$ and can

573 treat reasonably large areas inside the final product packaging. Small mobile handled CAP

574 devices could be an economical choice for AM sterilization inside the sterile area or

575 alternately, an on-bench contained chamber design for in-package sterilization may be more 576 applicable.

577

5786 CONCLUSION

579 Current terminal sterilization methods such as EtO, ionizing radiation, and chemical

580 sterilization methods have several disadvantages including toxicity, high running-costs, and

581 inefficacy against abnormal contamination. CAP is a terminal sterilization technique that is

582 applicable to living tissues without known harm or side effects, that has been proven to

583 destroy both normal and abnormal contamination. CAP is inexpensive but limited by tissue

584 thickness, post-packaging penetration, and reproducibility. Choice of CAP for TBTM

585 sterilization should be done on individual basis, dependent on tissue characteristics,

586 manufacturing protocol, and intended use. However, if CAP can be adapted for TBTM, it

587 holds a vast amount of promise.

588

589 ACKNOWLEDGMENTS

590 The authors alone are responsible for the content and writing of the manuscript. Funding

591 from The Authority for Research, Science, and Technology of the Ministry of Higher

592 Education and Scientific Research-Libya (Scholarship 404/2013) is gratefully acknowledged. 593 
595 REFERENCES

$596 \quad 1$

597 B. J. Lambert, T. A. Mendelson, M. D. Craven, AAPS Pharm. Sci. Tech. 2011, 12, 1116.

598 CrossRef | Web of Science ${ }^{\circledR}$ Times Cited: 13

$599 \quad 2$

600 D. Hussong, AAPS Pharm. Sci. Tech. 2010, 11, 1482.

601 CrossRef /Web of Science ${ }^{\circledR}$

6023

603 S. Stevenson, Orthop. Clin. North. Am. 1999, 30, 543.

604 CrossRef | PubMed | CAS | Web of Science ${ }^{\circledR}$ Times Cited: 117

6054

606 T. Boyce, J. Edwards, N. Scarborough, Orthop. Clin. North. Am. 1999, 30, 571.

607 CrossRef | PubMed | CAS | Web of Science ${ }^{\circledR}$ Times Cited: 170

6085

609 H. S. Dua, J. A. Gomes, A. J. King, V. S. Maharajan, Surv. Ophthalmol. 2004, 49, 51.

610 CrossRef | PubMed | Web of Science ${ }^{\circledR}$ Times Cited: 305

6116

612 F. Gindraux, R. Laurent, L. Nicod, B. de Billy, C. Meyer, N. Zwetyenga, L. Wajszczak, P.

613 Garbuio, L. Obert, Recent Pat. Regen. Med. 2013, 3, 193.

6147

615 J.-W. Lackmann, J. E. Bandow, Appl. Microbiol. Biotechnol. 2014, 98, 6205.

616 CrossRef | PubMed | CAS | Web of Science® Times Cited: 14

$617 \quad 8$

618 P. Brun, M. Vono, P. Venier, E. Tarricone, V. Deligianni, E. Martines, M. Zuin, S. Spagnolo,

619 R. Cavazzana, R. Cardin, I. Castagliuolo, A. L. Valerio, A. Leonardi, PLoS ONE 2012, 7, 14.

620 CrossRef | Web of Science ${ }^{\circledR}$ Times Cited: 32 | ADS

6219

622 C. Hoffmann, C. Berganza, J. Zhang, Med. Gas Res. 2013, 3, 21.

623 CrossRef|PubMed

$624 \quad 10$

625 C. Ulrich, F. Kluschke, A. Patzelt, S. Vandersee, V. A. Czaika, H. Richter, A. Bob, J. Hutten,

626 C. Painsi, R. Huge, A. Kramer, O. Assadian, J. Lademann, B. Lange-Asschenfeldt, J. Wound 627 Care 2015, 24, 198. 
628 CrossRef

$629 \quad 11$

630 R. Laurita, F. Alviano, C. Marchionni, P. M. Abruzzo, A. Bolotta, L. Bonsi, V. Colombo, M.

631 Gherardi, A. Liguori, F. Ricci, M. Rossi, A. Stancampiano, P. L. Tazzari, M. Marini, J. Phys.

632 D 2016, 49, 364003.

633 CrossRef | Web of Science ${ }^{\circledR} \mid$ ADS

63412

635 M. Hee Lee, B. Joo Park, S. Chang Jin, D. Kim, I. Han, J. Kim, S. O. Hyun, K.-H. Chung, J.-

636 C. Park, New J. Phys. 2009, 11, 115022.

637 CrossRef | Web of Science ${ }^{\circledR}$ Times Cited: 28 | ADS

63813

639 J. L. Zimmermann, K. Dumler, T. Shimizu, G. Morfill, A. Wolf, V. Boxhammer, J. Schlegel,

640 B. Gansbacher, M. Anton, J. Phys. D 2011, 44, 505201.

641 CrossRef | CAS | Web of Science ${ }^{\circledR}$ Times Cited: 33 | ADS

$642 \quad 14$

643 J. Komender, Ann. Transplant. 2004, 9, 88.

644 PubMed

64515

646 Council of Europe, Guide to Safety and Quality Assurance for Organs, Tissues and Cells, 2nd

647 ed., Council of Europe Publishing, Strasbourg, Belgium 2004.

$648 \quad 16$

649 H. Gillan, K. Bennett, P. Yates, Review of Long-Term Storage of Tissue Products, N.B.a.

650 Trnasplant, Editor. 2010, NHS Blood and Transplant: UK.

65117

652 F. D. A. U.S. Department of Health and Human Services, Minimal Manipulation of Human

653 Cells, Tissues, and Cellular and Tissue-Based Products - Draft Guidance for Industry and

654 Food and Drug Administartion Staff. FDA, New Hampshire Avenue, Silver Spring, USA

6552014.

$656 \quad 18$

657 S. Kuroda, A. S. Virdi, Y. Dai, S. Shott, D. R. Sumner, Calcif. Tissue Int. 2005, 77, 212.

658 CrossRef | PubMed | CAS | Web of Science® Times Cited: 30

65919

660 I. Mermet, N. Pottier, J. M. Sainthillier, C. Malugani, S. Cairey-Remonnay, S. Maddens, D.

661 Riethmuller, P. Tiberghien, P. Humbert, F. Aubin, Wound Repair Regen. 2007, 15, 459. 
662 Wiley Online Library | PubMed | Web of Science® Times Cited: 67

66320

664 F. E. Kruse, K. Rohrschneider, H. E. Völcker, Ophthalmology 1999, 106, 1504.

665 CrossRef | PubMed | CAS | Web of Science ${ }^{\circledR}$ Times Cited: 180

$666 \quad 21$

667 M. T. Rodríguez-Ares, R. Touriño, M. J. López-Valladares, F. Gude, Cornea 2004, 23, 577.

668 CrossRef | PubMed | Web of Science® Times Cited: 53

66922

670 P. J. Adds, C. Hunt, S. Hartley, Br. J. Ophthalmol. 2001, 85, 228.

671 CrossRef | PubMed | CAS | Web of Science ${ }^{\circledR}$ Times Cited: 19

$672 \quad 23$

673 Current Good Tissue Practice, American Association of Tissue Banks, McLean, Virginia.

6742006.

67524

676 International Standards for Tissue Banks, World Scientific, Singapore. 2003.

$677 \quad 25$

678 C. A. Combs, T. J. Garite, J. A. Lapidus, J. P. Lapointe, M. Gravett, J. Rael, E. Amon, J. K.

679 Baxter, K. Brady, W. Clewell, Am. J. Obstet. Gynecol. 2015, 212, 482.

680 PubMed

68126

682 SaBTO, Retrieval of Material for Donation Testing. Infectious Diseases and Blood Policy, 683 UK 2011.

$684 \quad 27$

685 S. Hill, AORN J. 2008, 88, 731.

686 CrossRef | PubMed

$687 \quad 28$

688 H. R. Aghayan, P. Goodarzi, A. Baradaran-Rafii, B. Larijani, L. Moradabadi, F. Rahim, B.

689 Arjmand, Cell Tissue Bank 2013, 14, 401.

690 CrossRef | PubMed | Web of Science ${ }^{\circledR}$ Times Cited: 2

$691 \quad 29$

692 A. Hopkinson, R. McIntosh, P. Tighe, D. James, H. S. Dua, Invest. Ophthalmol. Vis. Sci.

$6932006,47,4316$.

694 CrossRef | PubMed | Web of Science ${ }^{\circledR}$ Times Cited: 57

69530 
696 J. Morales Pedraza, A. Lobo Gajiwala, M. E. Martinez Pardo, Cell Tissue Bank 2012, 13, 15.

697 CrossRef | PubMed | CAS | Web of Science ${ }^{\circledR}$ Times Cited: 1

$698 \quad 31$

699 N. Yusof, A. Hassan, A. R. Shamsudin, A. C. Yong, M. N. F. A. Rahman, H. Mohamad, 700 Sterilisation of Tissues Using Ionising Radiations (Eds.: J. F. Kennedy, G. O. Phillips, P. A. 701 Williams), Woodhead Publishing Limited, Abington, Cambridge, England 2005, p. 319.

702 CrossRef

$703 \quad 32$

704 ISO-14160, Sterilization of health care products - Liquid chemical sterilizing agents for 705 single-use medical devices utilizing animal tissues and their derivatives - Requirements for 706 characterization, development, validation and routine control of a sterilization process for 707 medical devices, in The International Organization for Standardization. 2011 Geneva, 708 Switzerland.

70933

710 ISO-11137-1, Sterilization of health care products, Radiation, Part 1, Requirements for 711 development, validation and routine control of a sterilization process for medical devices, in 712 International Organization for Standardization. 2006: Geneva, Swetzerland.

$713 \quad 34$

714 ISO-11135, Sterilization of health care products - Ethylene Oxide - Requirements for

715 development, validation, and routine control of a sterilization process for medical devices, in

716 International Organization for Standardization. 2014: Geneva, Switzerland.

$717 \quad 35$

718 G. Ramachandran, Virulence 2014, 5, 213.

719 CrossRef | PubMed | Web of Science ${ }^{\circledR}$ Times Cited: 27

$720 \quad 36$

721 N. Mamalis, H. F. Edelhauser, D. G. Dawson, J. Chew, R. M. LeBoyer, L. Werner, J.

722 Cataract Refract. Surg. 2006, 32, 324.

723 CrossRef | PubMed | Web of Science® Times Cited: 116

$724 \quad 37$

725 E. T. Palva, P. H. Makela, Eur. J. Biochem. 1980, 107, 137.

726 Wiley Online Library | PubMed | CAS | Web of Science® Times Cited: 331

$727 \quad 38$

728 R. C. Goldman, L. Leive, Eur. J. Biochem. 1980, 107, 145.

729 Wiley Online Library | PubMed | CAS | Web of Science® Times Cited: 353 
731 T. Miyamoto, S. Okano, N. Kasai, Appl. Environ. Microbiol. 2009, 75, 5058.

732 CrossRef | PubMed | CAS | Web of Science® Times Cited: 9

73340

734 H. Mrazova, J. Koller, G. Fujerikova, P. Babal, Cell Tissue Bank 2014, 15, 429.

735 CrossRef | PubMed | CAS | Web of Science® Times Cited: 2

$736 \quad 41$

737 P. S-Juan, H. J. T. Ward, R. De Silva, R. S. G. Knight, R. G. Will, Br. J. Ophthalmol. 2004, $73888,446$.

739 CrossRef | PubMed | CAS | Web of Science® Times Cited: 6

$740 \quad 42$

741 S. Lerouge, Sterilization of Biomaterials and Medical Devices (Eds.: S. Lerouge, A.

742 Simmone), Woodhead Publishing Limited, Cambridge, UK 2012, p. 10.

743 CrossRef

$744 \quad 43$

745 M. M. Tuney, M. M. Tunney, N. Dunne, G. Einarsson, A. McDowell, A. Kerr, S. Patrick, J. 746 Ortho. Res. 2007, 25, 2.

747 Wiley Online Library | CAS | Web of Science® Times Cited: 37

$748 \quad 44$

749 P. Solves, V. Mirabet, M. Alvarez, World J. Gastroenterol. 2014, 20, 7434.

750 CrossRef | PubMed | Web of Science® Times Cited: 1

$751 \quad 45$

752 M. Silindir, A. Yekta Ozer, FABAD J. Pharm. Sci. 2009, 34, 43.

$753 \quad 46$

754 N. Yusof, Radiation in Tissue Banking - Basic Science and Clinical Applications of

755 Irradiated Tissue Allografts (Eds.: A. Nather, N. Yusof, N. Hilmy), ㄷ World Scientific

756 Publishing Co. Pte. Ltd., Singapore 2007, p. 129.

$757 \quad 47$

758 D. R. McAllister, M. J. Joyce, B. J. Mann, C. T. Vangsness, Jr., Am. J. Sports Med. 2007, 35, 7592148.

760 CrossRef | PubMed | Web of Science ${ }^{\circledR}$ Times Cited: 69

76148

762 F. von Versen-Hoynck, C. Syring, S. Bachmann, D. E. Moller, Cell Tissue Bank 2004, 5, 45.

763 CrossRef |PubMed 
765 ISO-17665, Sterilization of health care products - Moist heat — Part 1: Requirements for

766 the development, validation and routine control of a sterilization process for medical devices

767 in The International Organization for Standardization. 2006: Geneva, Switzerland.

76850

769 V. C. Abraham, D. L. Taylor, J. R. Haskins, Trends Biotechnol. 2004, 22, 15.

770 CrossRef | PubMed | CAS | Web of Science ${ }^{\circledR}$ Times Cited: 185

77151

772 ISO-11137-2, Sterilization of health care products - Radiation - Part 2: Establishing the

773 sterilization dose., in International Organization for Standardization. 2013: Geneva,

774 Switzerland.

$775 \quad 52$

776 Microbiological Surveillance Program and Process Validation American Association of

777 Tissue Banks, McLean, Virginia 2012.

$778 \quad 53$

779 Q. Q. Qiu, W. Q. Sun, J. Connor, Comprehensive Biomaterials (Ed.: P. Ducheyne), Elsevier,

780 Amsterdam, The Netherlands 2011, p. 127.

781 CrossRef

$782 \quad 54$

783 A. Dziedzic-Goclawska, A. Kaminski, I. Uhrynowska-Tyszkiewicz, W. Stachowicz, Cell

784 Tissue Bank 2005, 6, 201.

785 CrossRef | PubMed | CAS

78655

787 C. R. Balsly, A. T. Cotter, L. A. Williams, B. D. Gaskins, M. A. Moore, L. Wolfinbarger, Jr., 788 Cell Tissue Bank 2008, 9, 289.

789 CrossRef | PubMed | Web of Science ${ }^{\circledR}$ Times Cited: 49

$790 \quad 56$

791 R. Singh, P. Gupta, P. Kumar, A. Kumar, M. P. Chacharkar, Cell Tissue Bank 2003, 4, 95.

792 CrossRef |PubMed

$793 \quad 57$

794 N. Marsit, S. Dwejen, I. Saad, S. Abdalla, A. Shaab, S. Salem, E. Khanfas, A. Hasan, M.

795 Mansur, M. Abdul Sammad, Cell Tissue Bank 2014, 15, 603.

796 CrossRef | PubMed | Web of Science ${ }^{\circledR}$ Times Cited: 1

$797 \quad 58$ 
798 Radiation sterilization of tissue allografts:requirements for validation and routine control: a

799 code of practice, International Atomic Energy Agency, Vienna 2007.

$800 \quad 59$

801 S. Endres, M. Kratz, J. Musculoskelet Neuronal Interact 2009, 9, 25.

802 PubMed | Web of Science ${ }^{\circledR}$ Times Cited: 5

80360

804 B. E. Butterworth, J. R. Chapman, Regul. Toxicol. Pharmacol. 2007, 49, 149.

805 CrossRef | PubMed | CAS | Web of Science ${ }^{\circledR}$ Times Cited: 2

$806 \quad 61$

807 D. W. Jackson, G. E. Windler, T. M. Simon, Am. J. Sports Med. 1990, 18, 1.

808 CrossRef | PubMed | CAS | Web of Science ${ }^{\circledR}$ Times Cited: 194

80962

810 A. White, D. Burns, T. W. Christensen, J. Biotechnol. 2006, 123, 504.

811 CrossRef | PubMed | CAS | Web of Science ${ }^{\circledR}$ Times Cited: 74

81263

813 E. Shieh, A. Paszczynski, C. M. Wai, Q. Lang, R. L. Crawford, J. Microbiol. Methods 2009, $81476,247$.

815 CrossRef | PubMed | CAS | Web of Science® Times Cited: 18

$816 \quad 64$

817 W. A. Rutala, D. J. Weber, Am. J. Infect. Control 2013, 41, S2.

818 CrossRef | PubMed | Web of Science ${ }^{\circledR}$ Times Cited: 18

81965

820 A. Simmons, Sterilization of Biomaterials and Medical Devices. (Eds.: S. Lerouge, A.

821 Simmone), Woodhead Publishing Limited, Cambridge, UK 2012, p. 310.

822 CrossRef

$823 \quad 66$

824 M. Perrut, J. Supercrit Fluids 2012, 66, 359.

825 CrossRef | CAS | Web of Science ${ }^{\circledR}$ Times Cited: 21

$826 \quad 67$

827 M. S. a. H. P. P. Wutzler, J. Clin. Microbiol. 1975, 1, 246.

828 PubMed | Web of Science ${ }^{\circledR}$ Times Cited: 1

$829 \quad 68$

830 C. S. Frauke von Versen-Ḧoynck, S. Bachmann, D. E. M̈oller, Cell Tissue Bank 2004a, 5, 45.

831 CrossRef 
83269

833 P. D. Kemp, Peracetic Acid Sterilization of Collagen or Collagenous Tissue (Ed.: U. S.

834 Patent), Organogenesis Inc., Canton, Mass, USA 1995.

83570

836 A. Pruss, C. Perka, P. Degenhardt, U. Maronna, K. Buttner-Janz, B. Paul, K. Muller, C.

837 Klumpp, J. C. Bruck, R. Von Versen, Cell Tissue Bank 2002, 3, 235.

838 CrossRef | PubMed | CAS

83971

840 W. A. Rutala, D. J. Weber, Am. J. Infect. Control 2013, 41, S2.

841 CrossRef | PubMed | Web of Science ${ }^{\circledR}$ Times Cited: 18

$842 \quad 72$

843 S. Killeen, M. McCourt, Surgery 2012, 30, 687.

84473

845 W. A. Rutala, D. J. Weber, J. Hosp. Infect. 1999, 43, S43.

846 CrossRef | PubMed | Web of Science ${ }^{\circledR}$ Times Cited: 55

$847 \quad 74$

848 K. Shimizu, H. Yano, E. Nakamura, N. Kaku, Ann. Transplant. 2001, 6, 26.

849 PubMed

$850 \quad 75$

851 M. N. Bathina, S. Mickelsen, C. Brooks, J. Jaramillo, T. Hepton, F. M. Kusumoto, J. Am.

852 Coll. Cardiol. 1998, 32, 1384.

853 CrossRef | PubMed | CAS | Web of Science® Times Cited: 20

85476

855 S. D. Ferreira, W. S. Dernell, B. E. Powers, R. A. Schochet, C. A. Kuntz, S. J. Withrow, R. M.

856 Wilkins, Clin. Orthop. Relat. Res. 2001, 388, 233.

857 CrossRef

$858 \quad 77$

859 Y. Ikarashi, T. Tsuchiya, A. Nakamura, Biomaterials 1995, 16, 177.

860 CrossRef | PubMed | CAS | Web of Science ${ }^{\circledR}$ Times Cited: 20

86178

862 G. Fridman, G. Friedman, A. Gutsol, A. B. Shekhter, V. N. Vasilets, A. Fridman, Plasma

863 Process Polym. 2008, 5, 503.

864 Wiley Online Library |CAS | Web of Science® Times Cited: 722

86579 
866 J. Heinlin, G. Morfill, M. Landthaler, W. Stolz, G. Isbary, J. L. Zimmermann, T. Shimizu, S.

867 Karrer, J. Dtsch. Dermatol. Ges. 2010, 8, 968.

868 PubMed | Web of Science ${ }^{\circledR}$ Times Cited: 85

86980

870 M. Moreau, N. Orange, M. G. Feuilloley, Biotechnol. Adv. 2008, 26, 610.

871 CrossRef | PubMed | CAS | Web of Science ${ }^{\circledR}$ Times Cited: 190

87281

873 M. G. Kong, G. Kroesen, G. Morfill, T. Nosenko, T. Shimizu, J. van Dijk, J. L. Zimmermann, 874 New J. Phys. 2009, 11, 115012.

875 CrossRef | Web of Science ${ }^{\circledR}$ Times Cited: 587 | ADS

$876 \quad 82$

877 C. Cheng, L. Peng, X. Lei, Z. Li-Ye, Z. Ru-J., Chin. Phys. 2006, 15, 1544.

878 CrossRef | CAS | Web of Science ${ }^{\circledR}$ Times Cited: 30 | ADS

87983

880 O. Schlüter, J. Ehlbeck, C. Hertel, M. Habermeyer, A. Roth, K. H. Engel, T. Holzhauser, D.

881 Knorr, G. Eisenbrand, Mol. Nutr. Food Res. 2013, 57, 920.

882 Wiley Online Library | PubMed | CAS | Web of Science ${ }^{\circledR}$ Times Cited: 25

$883 \quad 84$

884 B. Haertel, T. von Woedtke, K.-D. Weltmann, U. Lindequist, Biomol. Ther. 2014, 22, 477.

885 CrossRef | CAS | Web of Science ${ }^{\circledR}$ Times Cited: 32

88685

887 R. Morent, N. De Geyter, Biomedical Engineering - Frontiers and Challenges (Ed.: R. Fazel),

888 In Tech, Rijeka, Croatia 2011, p. 25.

88986

890 L. Bárdos, H. Baránková, Vacuum 2008, 83, 522.

891 CrossRef | CAS | Web of Science® Times Cited: 16 | ADS

89287

893 K. P. Arjunan, V. K. Sharma, S. Ptasinska, Int. J. Mol. Sci. 2015, 16, 2971.

894 CrossRef | PubMed | Web of Science ${ }^{\circledR}$ Times Cited: 11

89588

896 M. Y. Alkawareek, S. P. Gorman, W. G. Graham, B. F. Gilmore, Int. J. Antimicrob. Agents $8972014,43,154$.

898 CrossRef | PubMed | CAS | Web of Science ${ }^{\circledR}$ Times Cited: 17

$899 \quad 89$ 
900 S. A. Ermolaeva, A. F. Varfolomeev, M. Y. Chernukha, D. S. Yurov, M. M. Vasiliev, A. A.

901 Kaminskaya, M. M. Moisenovich, J. M. Romanova, A. N. Murashev, I. I. Selezneva, T.

902 Shimizu, E. V. Sysolyatina, I. A. Shaginyan, O. F. Petrov, E. I. Mayevsky, V. E. Fortov, G. E.

903 Morfill, B. S. Naroditsky, A. L. Gintsburg, J. Med. Microbiol. 2011, 60, 75.

904 CrossRef | PubMed | CAS | Web of Science® Times Cited: 86

90590

906 G. Fridman, G. Friedman, A. Gutsol, A. B. Shekhter, V. N. Vasilets, A. Fridman, Plasma

907 Process Polym. 2008, 5, 503.

908 Wiley Online Library | CAS | Web of Science ${ }^{\circledR}$ Times Cited: 722

90991

910 X. Han, W. A. Cantrell, E. E. Escobara, S. Ptasinskab, Eur. Phys. J. D 2014, 68, 46.

911 CrossRef |CAS | Web of Science ${ }^{\circledR}$ Times Cited: 7 | ADS

91292

913 C. Sadiqali, M. Černák, M. Pavel, H. Josef, J. Appl. Biomed. 2010, 8, 55.

914 CrossRef | CAS | Web of Science ${ }^{\circledR}$ Times Cited: 39

91593

916 S. Emmert, F. Brehmer, H. Hänßle, A. Helmke, N. Mertens, R. Ahmed, D. Simon, D.

917 Wandke, W. Maus-Friedrichs, G. Däschlein, M. P. Schön, W. Viöl, Clin. Plasma Med. 2013, $9181,24$.

919 CrossRef

92094

921 G. Daeschlein, S. Scholz, R. Ahmed, T. von Woedtke, H. Haase, M. Niggemeier, E. Kindel,

922 R. Brandenburg, K. D. Weltmann, M. Juenger, J. Hosp. Infect. 2012, 81, 177.

923 CrossRef | PubMed | Web of Science ${ }^{\circledR}$ Times Cited: 38

92495

925 A. S. Wu, S. Kalghatgi, D. Dobrynin, R. Sensenig, E. Cerchar, E. Podolsky, E. Dulaimi, M.

926 Paff, K. Wasko, K. P. Arjunan, K. Garcia, G. Fridman, M. Balasubramanian, R. Ownbey, K.

927 A. Barbee, A. Fridman, G. Friedman, S. G. Joshi, A. D. Brooks, J. Surg. Res. 2013, 179, e1.

928 CrossRef | PubMed | Web of Science® Times Cited: 18

92996

930 B. Yang, J. Chen, Q. Yu, H. Li, M. Lin, A. Mustapha, L. Hong, Y. Wang, J. Dent. 2011, 39, 93148.

932 CrossRef | PubMed | Web of Science® Times Cited: 33

93397 
934 X. Zhou, Z. Xiong, Y. Cao, X. Lu, D. Liu, IEEE Trans. Plasma Sci. 2010, 38, 3370.

935 CrossRef | Web of Science ${ }^{\circledR}$ Times Cited: 14 | ADS

93698

937 N. O'Connor, O. Cahill, S. Daniels, S. Galvin, H. Humphreys, J. Hosp. Infect. 2014, 88, 59.

938 CrossRef | PubMed | Web of Science® Times Cited: 17

93999

940 M. R. Boscariol, A. J. Moreira, R. D. Mansano, I. S. Kikuchi, T. J. Pinto, Int. J. Pharm. 2008, $941353,170$.

942 PubMed | Web of Science ${ }^{\circledR}$ Times Cited: 11

943100

944 E. Curran, R. Duffy, D. Peretz, S. Park, B. Seiber, R. Smalley, A. Raghavan, M. Gurjar, D.

945 Dobrynin, K. Wasko, A. Fridman, G. Fridman, D. Paog, Plasma Med. 2013, 3, 153.

946 CrossRef

$947 \quad 101$

948 G. Avramidis, B. Stüwe, R. Wascher, M. Bellmann, S. Wieneke, A. von Tiedemann, W. Viöl, 949 Surf. Coat. Technol. 2010, 205, S405.

950 CrossRef | CAS | Web of Science ${ }^{\circledR}$ Times Cited: 7

951102

952 S. Ptasinska, B. Bahnev, A. Stypczynska, M. Bowden, N. J. Mason, N. S. Braithwaite, Phys.

953 Chem. Chem. Phys. 2010, 12, 7779.

954 CrossRef | PubMed | CAS | Web of Science ${ }^{\circledR}$ Times Cited: 27

955103

956 E. Stoffels, Y. Sakiyama, D. B. Graves, Plasma Sci. IEEE Trans. 2008, 36, 1441.

957 CrossRef | CAS | Web of Science ${ }^{\circledR}$ Times Cited: 182 | ADS

958104

959 D. A. Mendis, M. Rosenberg, F. Azam, IEEE Trans. Plasma Sci. 2000, 28, 1304.

960 CrossRef | Web of Science ${ }^{\circledR}$ Times Cited: 90 | ADS

961105

962 J. L. Zimmermann, T. Shimizu, H. U. Schmidt, Y. F. Li, G. E. Morfill, G. Isbary, New J.

963 Phys. 2012, 14, 073037.

964 CrossRef | Web of Science ${ }^{\circledR}$ Times Cited: 17 | ADS

965106

966 M. Laroussi, F. Leipold, Int. J. Mass Spectrom. 2004, 233, 81.

967 CrossRef | CAS | Web of Science ${ }^{\circledR}$ Times Cited: 324 | ADS 
969 M. Laroussi, Plasma Process Polym. 2005, 2, 391.

970 Wiley Online Library | CAS | Web of Science ${ }^{\circledR}$ Times Cited: 492

971108

972 M. L. Burts, I. Alexeff, E. T. Meek, J. A. McCullers, Am. J. Infect. Control 2009, 37, 729.

973 CrossRef | PubMed | Web of Science® Times Cited: 21

974109

975 E. Kvam, B. Davis, F. Mondello, A. L. Garner, Antimicrob. Agents Chemother. 2012, 56, 9762028.

977 CrossRef | PubMed | CAS | Web of Science® Times Cited: 39

978110

979 T. Maisch, T. Shimizu, Y. F. Li, J. Heinlin, S. Karrer, G. Morfill, J. L. Zimmermann, PLoS

980 ONE 2012, 7, e34610.

981 CrossRef | PubMed | Web of Science ${ }^{\circledR}$ Times Cited: 47 | ADS

982111

983 T. Maisch, T. Shimizu, A. Mitra, J. Heinlin, S. Karrer, Y. F. Li, G. Morfill, J. L.

984 Zimmermann, J. Ind. Microbiol. Biotechnol. 2012, 39, 1367.

985 CrossRef | PubMed | CAS | Web of Science® Times Cited: 13

986112

987 C. M. Edelblute, M. A. Malik, L. C. Heller, Bioelectrochemistry 2015, 103, 22.

988 CrossRef | PubMed | CAS | Web of Science® Times Cited: 4

989113

990 M. Korachi, C. Gurol, N. Aslan, J. Electrostat. 2010, 68, 508.

991 CrossRef | CAS | Web of Science ${ }^{\circledR}$ Times Cited: 20

992114

993 A. Fernandez, N. Shearer, D. R. Wilson, A. Thompson, Int. J. Food. Microbiol. 2012, 152,

994175.

995 CrossRef | PubMed | Web of Science® Times Cited: 25

$996 \quad 115$

997 J. J. Cotter, P. Maguire, F. Soberon, S. Daniels, J. P. O'Gara, E. Casey, J. Hosp. Infect. 2011, $99878,204$.

999 CrossRef | PubMed | Web of Science® Times Cited: 19

1000116 
1001 C. Wei, H. Jun, D. Ning, L. Xiao-Di, L. Guo-Hua, W. Xing-Quan, Z. Guo-Ping, G. Li-Hong, 1002 Y. Si-Ze, Chin. Phys. Lett. 2012, 29, 075203.

1003 CrossRef | CAS | Web of Science ${ }^{\circledR}$ Times Cited: 3 | ADS

$1004 \quad 117$

1005 R. Matthes, C. Bender, R. Schluter, I. Koban, R. Bussiahn, S. Reuter, J. Lademann, K. D.

1006 Weltmann, A. Kramer, PLoS ONE 2013, 8, e70462.

1007 CrossRef | PubMed | Web of Science ${ }^{\circledR}$ Times Cited: 15 | ADS

$1008 \quad 118$

1009 O. Lademann, A. Kramer, H. Richter, A. Patzelt, M. Meinke, J. Roewert-Huber, V. Czaika, K.

1010 Weltmann, B. Hartmann, S. Koch, Laser Phys. Lett. 2011, 8, 313.

1011 Wiley Online Library | Web of Science ${ }^{\circledR}$ Times Cited: 19

1012119

1013 O. Lademann, A. Kramer, H. Richter, A. Patzelt, M. Meinke, V. Czaika, K. -D. Weltmann, B.

1014 Hartmann, S. Koch, Skin Pharmacol. Physiol. 2011, 24, 284.

1015 CrossRef | PubMed | CAS | Web of Science ${ }^{\circledR}$ Times Cited: 26

1016120

1017 A. Ali, Y. H. Kim, J. Y. Lee, S. Lee, H. S. Uhm, G. Cho, B. J. Park, E. H. Choi, Curr. Appl.

1018 Phys. 2014, 14, S142.

1019 CrossRef | Web of Science ${ }^{\circledR}$ Times Cited: 1

$1020 \quad 121$

1021 Y. F. Hong, J. G. Kang, H. Y. Lee, H. S. Uhm, E. Moon, Y. H. Park, Lett. Appl. Microbiol. 1022 2009, 48, 33.

1023 Wiley Online Library | PubMed | CAS | Web of Science ${ }^{\circledR}$ Times Cited: 44

1024122

1025 S. Shimizu, S. Barczyk, P. Rettberg, T. Shimizu, T. Klaempfl, J. L. Zimmermann, T.

1026 Hoeschen, C. Linsmeier, P. Weber, G. E. Morfill, H. M. Thomas, Plant. Space Sci. 2014, 90, 102760.

1028 CrossRef | Web of Science ${ }^{\circledR}$ Times Cited: 7| ADS

$1029 \quad 123$

1030 J. Jeon, T. Klaempfl, J. Zimmermann, G. Morfill, T. Shimizu, New J. Phys. 2014, 16, 103007.

1031 CrossRef | Web of Science ${ }^{\circledR}$ Times Cited: 2 | ADS

$1032 \quad 124$

1033 S. Patil, T. Moiseev, N. N. Misra, P. J. Cullen, J. P. Mosnier, K. M. Keener, P. Bourke, J.

1034 Hosp. Infect. 2014, 88, 162. 
1035 CrossRef | PubMed | Web of Science ${ }^{\circledR}$ Times Cited: 10

1036125

1037 F. Rossi, O. Kylián, Sterilisation of Biomaterials and Medical Devices (Eds.: S. Lerouge, A.

1038 Simmons), Woodhead Publishing Series in Biomaterials, Philadelphia, USA 2012, p. 117.

1039 CrossRef

1040126

1041 H. Shintani, Biocontrol. Sci. 2016, 21, 63.

1042 CrossRef | PubMed | Web of Science ${ }^{\circledR}$

$1043 \quad 127$

1044 B. J. Park, K. Takatori, M. H. Lee, D. -W. Han, Y. I. Woo, H. J. Son, J. K. Kim, K.-H. Chung, 1045 S. O. Hyun, J.-C. Park, Surf. Coat. Technol. 2007, 201, 5738.

1046 CrossRef |CAS | Web of Science ${ }^{\circledR}$ Times Cited: 29

1047128

1048 D. L. Bayliss, J. L. Walsh, G. Shama, F. Iza, M. G. Kong, New J. Phys. 2009, 11, 115024.

1049 CrossRef | Web of Science ${ }^{\circledR}$ Times Cited: 26 | ADS

1050129

1051 J. Julák, O. Janoušková, V. Scholtz, K. Holada, Plasma Process Polym. 2011, 8, 316.

1052 Wiley Online Library |CAS | Web of Science® Times Cited: 17

1053130

1054 A. Holmberg, R. Lood, M Mörgelin, B. Söderquist, E. Holst, M. Collin, B. Christensson, M.

1055 Rasmussen, Clin. Microbiol. Infect. 2009, 15, 787.

1056 Wiley Online Library | PubMed | Web of Science ${ }^{\circledR}$ Times Cited: 53

1057131

1058 T. Maisch, T. Shimizu, G. Isbary, J. Heinlin, S. Karrer, T. G. Klampfl, Y. F. Li, G. Morfill, J.

1059 L. Zimmermann, Appl. Environ. Microbiol. 2012, 78, 4242.

1060 CrossRef | PubMed | CAS | Web of Science ${ }^{\circledR}$ Times Cited: 31

1061132

1062 K. Fricke, I. Koban, H. Tresp, L. Jablonowski, K. Schroder, A. Kramer, K. D. Weltmann, T.

1063 von Woedtke, T. Kocher, PLoS ONE 2012, 7, e42539.

1064 CrossRef | PubMed | Web of Science ${ }^{\circledR}$ Times Cited: 35 | ADS

1065133

1066 H. Yasuda, T. Miura, H. Kurita, K. Takashima, A. Mizuno, Plasma Process Polym. 2010, 7, 1067301.

1068 Wiley Online Library | CAS | Web of Science® Times Cited: 45 
1070 A. Mai-Prochnow, A. B. Murphy, K. M. McLean, M. G. Kong, K. K. Ostrikov, Int. J.

1071 Antimicrob. Agents 2014, 43, 508.

1072 CrossRef | PubMed | CAS | Web of Science ${ }^{\circledR}$ Times Cited: 35

1073135

1074 S. Bekeschus, A. Schmidt, K.-D. Weltmann, T. von Woedtke, Clin. Plasma Med. 2016, 4, 19.

1075 CrossRef

1076136

1077 F. Brehmer, H. A. Haenssle, G. Daeschlein, R. Ahmed, S. Pfeiffer, A. Gorlitz, D. Simon, M.

1078 P. Schon, D. Wandke, S. Emmert, J. Eur. Acad. Dermatol. Venereol. 2015, 29, 148.

1079 Wiley Online Library | PubMed | CAS | Web of Science ${ }^{\circledR}$ Times Cited: 20

1080137

1081 E. Stoffels, I. E. Kieft, R. E. J. Sladek, J. Phys. D Appl. Phys. 2003, 36, 2908.

1082 CrossRef | CAS | Web of Science ${ }^{\circledR}$ Times Cited: 136 | ADS

1083138

1084 T Jiang, H. Zhao, C. Wang, G. Rao, A. Li, H. Tolner, B. Li, Plasma Med. 2012, 2, 179.

1085 CrossRef

1086139

1087 E. Stoffels, A. J. Flikweert, W. W. Stoffels, G. M. W. Kroesen, Plasma Sources Sci. Technol. 1088 2002, 11, 383.

1089 CrossRef | CAS | Web of Science® Times Cited: 355 | ADS

1090140

1091 C. Welz, S. Becker, Y.-F. Li, T. Shimizu, J. Jeon, S. Schwenk-Zieger, H. M. Thomas, G.

1092 Isbary, G. E. Morfill, U. Harréus, J. Phys. D Appl. Phys. 2013, 46, 045401.

1093 CrossRef | CAS | Web of Science ${ }^{\circledR}$ Times Cited: 10 | ADS

1094141

1095 X. Pei, X. Lu, J. Liu, D. Liu, Y. Yang, K. Ostrikov, K. C. Paul, Y. Pan, J. Phys. D Appl. Phys. 1096 2012, 45, 165205.

1097 CrossRef | CAS | Web of Science ${ }^{\circledR}$ Times Cited: 44 | ADS

1098142

1099 D. Dobrynin, G. Fridman, G. Friedman, A. Fridman, New J. Phys. 2009, 11, 115020.

1100 CrossRef $\mid$ ADS

1101143

1102 A. H. Tehrani, P. Davari, S. Singh, A. Oloyede, J. Mater. Sci. Mater. Med. 2014, 25, 953. 
1103 CrossRef | PubMed | CAS | Web of Science ${ }^{\circledR}$ Times Cited: 3

1104144

1105 E. J. Szili, J. W. Bradley, R. D. Short, J. Phys. D 2014, 47, 152002.

1106 CrossRef | CAS | Web of Science ${ }^{\circledR}$ Times Cited: 22 | ADS

1107145

1108 D. Dobrynin, G. Fridman, G. Friedman, A. A. Fridman, Plasma Med. 2012, 2, 71.

1109 CrossRef

1110146

1111 C. X. Wang, Y. Liu, H. L. Xu, Y. Ren, Y. P. Qiu, Appl. Surf. Sci. 2008, 254, 2499.

1112 CrossRef |CAS | Web of Science ${ }^{\circledR}$ Times Cited: 51 | ADS

1113147

1114 C. X. Wang, Y. P. Qiu, Surf. Coat. Technol. 2007, 201, 6273.

1115 CrossRef | CAS | Web of Science® Times Cited: 69

1116148

1117 K. Heuer, M. A. Hoffmanns, E. Demir, S. Baldus, C. M. Volkmar, M. Rohle, P. C. Fuchs, P.

1118 Awakowicz, C. V. Suschek, C. Oplander, Nitric Oxide 2015, 44, 52.

1119 CrossRef | PubMed | CAS | Web of Science ${ }^{\circledR}$ Times Cited: 13

1120149

1121 F. von Versen-Hoeynck, A. P. Steinfeld, J. Becker, M. Hermel, W. Rath, U. Hesselbarth,

1122 Biologicals 2008, 36, 248.

1123 CrossRef | PubMed | CAS | Web of Science ${ }^{\circledR}$ Times Cited: 17

$1124 \quad 150$

1125 E. Noriega, G. Shama, A. Laca, M. Díaz, M. G. Kong, Food Microbiol. 2011, 28, 1293.

1126 CrossRef | PubMed | CAS | Web of Science ${ }^{\circledR}$ Times Cited: 59

$1127 \quad 151$

1128 S. S. Ab Hamid, N. K. Zahari, N. Yusof, A. Hassan, Cell Tissue Bank 2014, 15, 15.

1129 CrossRef | PubMed | Web of Science® Times Cited: 5

1130152

1131 Z. Nor Kamilia, Y. N. Suzina SAH, Regen. Res. 2014, 3, 64.

1132153

1133 R. Singh, M. P. Chacharkar, J. Tissue Viability 2011, 20, 49.

1134 CrossRef | PubMed | Web of Science ${ }^{\circledR}$ Times Cited: 7

$1135 \quad 154$

1136 S. Kitazaki, A. Tanaka, N. Hayashi, Vacuum 2014, 110, 217. 
1137 CrossRef |CAS | Web of Science ${ }^{\circledR}$ Times Cited: 5 | ADS

1138155

1139 M. Annunziata, L. Canullo, G. Donnarumma, P. Caputo, L. Nastri, L. Guida, Med. Oral Patol.

1140 Oral Cir. Bucal 2016, 21, e118.

1141 CrossRef | PubMed | Web of Science® Times Cited: 1

1142156

1143 E. Simoncelli, D. Barbieri, R. Laurita, A. Liguori, A. Stancampiano, L. Viola, R. Tonini, M.

1144 Gherardi, V. Colombo, Clin. Plasma Med. 2015, 3, 77.

1145 CrossRef

$1146 \quad 157$

1147 C.-W. Kan, C.-F. Lam, C.-K. Chan, S.-P. Ng, Carbohydr. Polym. 2014, 102, 167.

1148 CrossRef | PubMed | CAS | Web of Science ${ }^{\circledR}$ Times Cited: 10

1149158

1150 L. Bárdos, H. Baránková, Thin Solid Films 2010, 518, 6705.

1151 CrossRef | CAS | Web of Science ${ }^{\circledR}$ Times Cited: 85 | ADS

1152159

1153 C. Wang, Y. Qiu, Surf. Coat. Technol. 2007, 201, 6273.

1154 CrossRef |CAS | Web of Science® Times Cited: 69

1155160

1156 S. Lerouge, M. R. Wertheimer, L. Yahia, Plasmas Polym. 2001, 6, 175.

1157 CrossRef |CAS

1158161

1159 E. Stoffels, I. E. Kieft, R. E. J. Sladek, L. J. M. v. d. Bedem, E. P. v. d. Laan, M. Steinbu,

1160 Plasma Sources Sci. Technol. 2006, 15, S169.

1161 CrossRef | CAS | Web of Science® Times Cited: 173 | ADS

1162162

1163 N. De Geyter, R. Morent, Annu. Rev. Biomed. Eng. 2012, 14, 255.

1164 CrossRef | PubMed | CAS | Web of Science ${ }^{\circledR}$ Times Cited: 26

1165163

1166 S. Pankaj, N. Misra, P. Cullen, Innov. Food Sci. Emerg. Technol. 2013, 19, 153.

1167 CrossRef | CAS | Web of Science® Times Cited: 29

1168164

1169 H. Eto, Y. Ono, A. Ogino, M. Nagatsu, Appl. Phys. Lett. 2008, 93, 221502.

1170 CrossRef | CAS | Web of Science ${ }^{\circledR}$ Times Cited: 36 | ADS 
$1171 \quad 165$

1172 T. Lee, P. Puligundla, C. Mok, Food Control 2015, 51, 149.

1173 CrossRef | PubMed | CAS | Web of Science ${ }^{\circledR}$ Times Cited: 7

1174166

1175 H. I. Yong, H. -J. Kim, S. Park, A. U. Alahakoon, K. Kim, W. Choe, C. Jo, Food Microbiol. 1176 2015, 46, 46.

1177 CrossRef | PubMed | CAS | Web of Science ${ }^{\circledR}$ Times Cited: 14

1178167

1179 O. V. Penkov, M. Khadem, W. -S. Lim, D. -E. Kim, J. Coat. Technol. Res. 2015, 12, 225.

1180 CrossRef | CAS | Web of Science ${ }^{\circledR}$ Times Cited: 8

1181168

1182 C. Wiegand, M. Abel, P. Ruth, T. Wilhelms, D. Schulze, J. Norgauer, U. -C. Hipler, J.

1183 Biomed. Mater. Res. B Appl. Biomater. 2009, 90, 710.

1184 Wiley Online Library | PubMed | CAS | Web of Science ${ }^{\circledR}$ Times Cited: 21

1185169

1186 E. Y. Elenes, S. A. Hunter, J. Bone Joint Surg. Am. 2014, 96, 1321.

1187 CrossRef | PubMed | Web of Science ${ }^{\circledR}$ Times Cited: 3

1188170

1189 C. M. Deeley, Radiat. Phys. Chem. 2004, 71, 505.

1190 CrossRef | CAS | Web of Science ${ }^{\circledR}$ Times Cited: 1 | ADS

$1191 \quad 171$

1192 D. Cheung, N. Perelman, D. Tong, M. Nimni, J. Biomed. Mater. Res. 1990, 24, 581.

1193 Wiley Online Library | PubMed | CAS | Web of Science ${ }^{\circledR}$ Times Cited: 95

1194172

1195 S. Baloda, J. Martin, J. Carter, E. Jenness, B. Judd, K. Smeltz, I. Uettwiller, M. Hockstad,

1196 Guide to irradiation and sterilization of single-use bioprocess components and systems. The

1197 Society of the Plastics Industry, Inc. The irradiation and sterilization subcommittee of the

1198 bioprocess systems alliance, 2008, 2, 10.

1199173

1200 A. Hoburg, S. Keshlaf, T. Schmidt, M. Smith, U. Gohs, C. Perka, A. Pruss, S. Scheffler, Cell

1201 Tissue Bank 2014, 16, 219.

1202 CrossRef | PubMed | CAS | Web of Science ${ }^{\circledR}$ Times Cited: 2

$1203 \quad 174$

1204 M. Smith, R. Galloway, Radiat. Phys. Chem. 2004, 71, 531. 
1205 CrossRef | CAS | Web of Science ${ }^{\circledR} \mid$ ADS

1206175

1207 G. da Cunha Mendez, T. da Silva Brandao, C. Miranda Silva, Expert Rev. Med. Devices

$12082008,5,323$.

1209 CrossRef $\mid$ PubMed | CAS

1210176

1211 G. C. Mendes, T. R. Brandao, C. L. Silva, Am. J. Infect. Control 2007, 35, 574.

1212 CrossRef | PubMed | Web of Science® Times Cited: 66

1213177

1214 T. M. Moore, E. Gendler, J. Orthop. Res. 2004, 22, 1358.

1215 Wiley Online Library | PubMed | CAS | Web of Science ${ }^{\circledR}$ Times Cited: 10

1216178

1217 A. Nather, J. L. L. Chew, Z. Aziz, Radiation in Tissue Banking - Basic Science and Clinical

1218 Applications of Irradiated Tissue Allografts (Eds.: A. Nather, N. Yusof, N. Hilmy), (C) World

1219 Scientific Publishing Co. Pte. Ltd., Singapore 2007.

1220 CrossRef

1221179

1222 ISO-10993-7, Biological evaluation of medical devices - Part 7: Ethylene oxide sterilization

1223 residuals., in The International Organization for Standardization. 2008: Geneva, Swetzerland.

1224180

1225 T. S. Roberts, D. Drez, Jr., W. McCarthy, R. Paine, Am. J. Sports Med. 1991, 19, 35.

1226 CrossRef | PubMed | CAS | Web of Science® Times Cited: 109

$1227 \quad 181$

1228 Ethylene Oxide (EtO): Evidence of Carcinogenicity, U.S. Department of Health and Human

1229 Services, National Institute for Occupational Safety and Health, USA 1981.

$1230 \quad 182$

1231 K. Steenland, E. Whelan, J. Deddens, L. Stayner, E. Ward, Cancer Causes Control 2003, 14, 1232531.

1233 CrossRef | PubMed | Web of Science ${ }^{\circledR}$ Times Cited: 23

$1234 \quad 183$

1235 V. M. Steelman, AORN J. 1992, 55, 773.

1236 CrossRef | PubMed | CAS

$1237 \quad 184$ 
Preventing worker injuries and deaths from explosions in industrial ethylene oxide sterilization facilities, Public Health Service, Centers for Disease Control and Prevention,

1240 National Institute for Occupational Safety and Health, Atlanta, GA 2007.

1241185

1242 C. T. Vangsness, Jr., P. P. Wagner, T. M. Moore, M. R. Roberts, Arthroscopy 2006, 22, 1351.

1243 CrossRef | PubMed | Web of Science ${ }^{\circledR}$ Times Cited: 32

1244186

1245 Y. C. Chien, H. H. Liu, Y. C. Lin, P. C. Su, L. H. Li, C. P. Chang, D. T. Tang, C. Y. Chen, J.

1246 Biomed. Mater. Res. B Appl. Biomater. 2007, 83, 527.

1247 Wiley Online Library | PubMed | CAS | Web of Science ${ }^{\circledR}$ Times Cited: 8

1248187

1249 B. J. Park, K. Takatori, M. H. Lee, D.-W. Han, Y. I. Woo, H. J. Son, J. K. Kim, K.-H. Chung,

1250 S. O. Hyun, J. -C. Park, Surf. Coat. Technol. 2007, 201, 5738.

1251 CrossRef |CAS | Web of Science ${ }^{\circledR}$ Times Cited: 29

1252188

1253 B. A. Niemira, J. Food Sci. 2012, 77, M171.

1254 Wiley Online Library | PubMed | CAS | Web of Science ${ }^{\circledR}$ Times Cited: 29

1255189

1256 A. Blumhagen, P. Singh, A. Mustapha, M. Chen, Y. Wang, Q. Yu, Am. J. Dent. 2014, 27, 84.

1257 PubMed | Web of Science ${ }^{\circledR}$ Times Cited: 3

1258190

1259 P. Sun, Y Sun, H. Wu, W. Zhu, J. L. Lopez, W. Liu, J. Zhang, R. Li, J. Fang, Appl. Phys.

1260 Lett. 2011, 98, 021501.

1261 CrossRef | CAS | Web of Science ${ }^{\circledR}$ Times Cited: 29 | ADS

1262191

1263 B. Dasan, M. Mutlu, I. Boyaci, Int. J. Food Microbiol. 2016, 216, 50.

1264 CrossRef | PubMed | CAS | Web of Science ${ }^{\circledR}$ Times Cited: 3

1265192

1266 M. Selcuk, L. Oksuz, P. Basaran, Bioresour. Technol. 2008, 99, 5104.

1267 CrossRef | PubMed | CAS | Web of Science ${ }^{\circledR}$ Times Cited: 80

1268193

1269 N. S. Panikov, S. Paduraru, R. Crowe, P. J. Ricatto, C. Christodoulatos, K. Becker, IEEE

1270 Trans. Plasma Sci. 2002, 30, 1424.

1271 CrossRef | Web of Science ${ }^{\circledR}$ Times Cited: 43 | ADS 
1273 R. A. Venezia, M. Orrico, E. Houston, S. M. Yin, Y. Y. Naumova, Infect. Contol Hosp.

1274 Epidemiol. 2008, 29, 430.

1275 CrossRef | PubMed | Web of Science ${ }^{\circledR}$ Times Cited: 35

1276195

1277 N. Alshraiedeh, M. Alkawareek, S. Gorman, W. Graham, B. Gilmore, J. Appl. Microbiol. 1278 2013, 115, 1420.

1279 Wiley Online Library | PubMed | CAS | Web of Science ${ }^{\circledR}$ Times Cited: 12 1280196

1281 O. Terrier, B. Essere, M. Yver, M. Barthélémy, M. Bouscambert-Duchamp, P. Kurtz, D.

1282 VanMechelen, F. Morfin, G. Billaud, O. Ferraris, J. Clin. Virol. 2009, 45, 119.

1283 CrossRef | PubMed | CAS | Web of Science ${ }^{\circledR}$ Times Cited: 22

$1284 \quad 197$

1285 D. Ziuzina, L. Han, P. J. Cullen, P. Bourke, Int. J. Food Microbiol. 2015, 210, 53.

1286 CrossRef | PubMed | Web of Science ${ }^{\circledR}$ Times Cited: 5

$1287 \quad 198$

1288 M. Moisan, P. Levif, J. Séguin, J. Barbeau, J. Phys. D Appl. Phys. 2014, 47, 285404.

1289 CrossRef | CAS | Web of Science ${ }^{\circledR}$ Times Cited: 1 | ADS

1290199

1291 Q. Y. Nie, Z. Cao, C. S. Ren, D. Z. Wang, M. G. Kong, New J. Phys. 2009, 11, 115015.

1292 CrossRef | Web of Science ${ }^{\circledR}$ Times Cited: 44 | ADS

1293200

1294 A. N. Aleynik, A. N. Baykov, M. B. Baskakov, G. T. Dambaev, O. I. Deneko, E. P.

1295 Krasnozhenov, E. V. Semichev, O. S. Zhdanova, Strategic Technology (IFOST), 2012 7th

1296 International Forum, Tomsk Polytechnic University, Russia 2012.

1297 Related content

1298 